Calamari, N. C., F. J. Vilella, Y. V. Sica, and P. A. Mercuri. 2018. Patch and landscape responses of bird abundance to fragmentation in agroecosystems of east-central Argentina. Avian Conservation and Ecology 13(2):3. https://doi.org/10.5751/ACE-01222-130203

Copyright (C) 2018 by the author(s). Published here under license by the Resilience Alliance.

Research Paper

\title{
Patch and landscape responses of bird abundance to fragmentation in agroecosystems of east-central Argentina
}

\author{
Noelia C. Calamari ${ }^{1}$, Franciso J. Vilella ${ }^{2,3}$, Yanina V. Sica ${ }^{4}$ and Pablo A. Mercuri ${ }^{5}$ \\ ${ }^{1}$ Estación Experimental Agropecuaria Paraná, Instituto Nacional de Tecnología Agropecuaria (INTA), Entre Ríos, Argentina, ${ }^{2}$ U.S. \\ Geological Survey, Mississippi Cooperative Fish and Wildlife Research Unit, ${ }^{3}$ Department of Wildlife, Fisheries and Aquaculture, \\ Mississippi State University, USA, ${ }^{4}$ Instituto de Investigación e Ingeniería Ambiental (3iA), Universidad Nacional de San Martín \\ (UNSAM), Buenos Aires, Argentina, ${ }^{5}$ Centro de Investigación de Recursos Naturales (CIRN), Instituto Nacional de Tecnología \\ Agropecuaria (INTA), Buenos Aires, Argentina
}

\begin{abstract}
Forest fragmentation in agroecosystems is linked to declines of avian species worldwide. Agriculture has greatly reduced native forest cover in east-central Argentina. Assessing the influence of fragmentation on forest bird populations is vital to inform reliable conservation and management strategies for the Espinal region of Argentina. We determined the relationships of vegetation structure within native forest patches, size and shape of these patches (patch scale), composition and spatial configuration (at landscape scale) to relative abundance of 17 forest bird species during austral fall-winter and spring-summer seasons. Birds were sampled from 2007-2009 in 45 forest patches within three landscape mosaics (30 x $30 \mathrm{~km})$ representing a gradient of native forest fragmentation in east-central Argentina. We used an information-theoretic approach and approximated model inference to examine the effect of predictor environmental variables at two spatial scales on patterns of forest bird abundance. Density of trees within forest patches was the main predictor of bird abundance at the patch scale. Amount of forest and spatial configuration were also important. The abundance of several bird species was greater in patches with high density of trees and landscapes characterized by more forest cover and larger patches in close proximity. We found two main avian response patterns to forest fragmentation and patch characteristics. This information contributes reliable knowledge for the design of conservation measures of agricultural landscapes in the Espinal region of Argentina.
\end{abstract}

\section{Abondance d'oiseaux dans les îlots et les paysages à la suite de la fragmentation dans des agrosystèmes du centre-est de l'Argentine}

RÉSUMÉ. La fragmentation forestière dans les agrosystèmes est liée à la diminution d'espèces aviaires partout dans le monde. L'agriculture a grandement réduit la superficie de forêts indigènes dans le centre-est de l'Argentine. L'évaluation de l'influence de la fragmentation sur les populations d'oiseaux forestiers est cruciale pour que les gestionnaires puissent choisit des stratégies de conservation et de gestion fiables dans la région de l'Espinal en Argentine. Nous avons déterminé les relations de la structure de la végétation dans les îlots forestiers, de la taille et de la forme de ces îlots (échelle des îlots), de la composition et de la configuration spatiale (à l'échelle du paysage) avec l'abondance relative de 17 espèces d'oiseaux forestiers durant les saisons automne-hiver et printempsété austraux. Les oiseaux ont été échantillonnés de 2007 à 2009 dans 45 îlots forestiers se trouvant dans 3 mosaïques paysagères (30 x $30 \mathrm{~km}$ ) représentatives d'un gradient de fragmentation de la forêt indigène dans le centre-est de l'Argentine. Nous avons utilisé une approche fondée sur la théorie de l'information et un modèle d'inférence flou pour examiner l'effet des variables environnementales explicatives sur la tendance de l'abondance des oiseaux forestiers aux deux échelles spatiales. La densité d'arbres dans les îlots forestiers était la principale variable explicative de l'abondance à l'échelle des îlots. La superficie de forêt et la configuration spatiale étaient aussi importantes. L'abondance de plusieurs espèces d'oiseaux était supérieure dans les îlots où la densité d'arbres était élevée et dans les paysages caractérisés par une plus grande superficie de couvert forestier et par de plus grands îlots près les uns des autres. Nous avons trouvé deux types principaux de réaction des oiseaux à la fragmentation forestière et aux caractéristiques des îlots. Ces résultats contribuent à une connaissance plus éclairée en vue d'élaborer des mesures de conservation de paysages agricoles dans la région de l'Espinal en Argentine.

Key Words: agroecosystem; birds; Espinal; multimodel inference; patch and landscape scales

\section{INTRODUCTION}

Habitat loss and fragmentation as consequences of land use changes are major drivers of global biodiversity loss (Baillie et al. 2004, Renfrew and Ribic 2008). These processes in turn may modify the composition, structure, or function of landscapes
(Fraterrigo et al. 2009, Magrach et al. 2011). Further, fragmentation may alter the original configuration of a landscape, generating isolated patches immersed in a frequently hostile matrix (Forman 1995, McComb 1999, Fahrig 2003). Both processes can negatively influence the abundance, movement, and 
dispersal of birds (Mazerolle and Villard 1999, Zurita and Bellocq 2007, Prugh et al. 2008). This may negatively influence demography and long-term persistence of bird populations, and affect key ecological roles of ecosystem function (Lundberg and Moberg 2003, Hanski 2011, Ye et al. 2013).

Forest ecosystems around the world are among the most affected by habitat loss and fragmentation, in many cases driven by the expansion and intensification of agricultural activities (Geist and Lambin 2002, Hoekstra et al. 2005, Gasparri and Grau 2009). In recent decades, the greatest loss of forests worldwide have occurred in the tropics, particularly in South America and Africa where annual rates of forest loss of $0.43 \%$ and $0.54 \%$, respectively, have been reported (FAO 2016). With a loss of 297,000 hectares of forest/year (1.1\%/year; FAO 2016), Argentina ranked as one of the top 10 countries with the greatest annual net loss of forest area during 2010 to 2015. In the province of Entre Ríos, located in east-central Argentina, the agricultural frontier has greatly expanded, despite soils poorly suited for production (Wilson 2008). Landscape composition and spatial configuration of native Espinal forest have changed during the past century. Forest cover in the province of Entre Ríos decreased from 56\% in 1914 to approximately $13.8 \%$ at present (Muñoz et al. 2005, De la Fuente and Suárez 2008, Aizen et al. 2009). This has resulted in a subsequent loss of avian diversity in the region (Schrag et al. 2009, Gavier-Pizarro et al. 2012).

Bird species respond differently to environmental changes in fragmented landscapes, exhibiting both negative and positive effects (Antongiovanni and Metzger 2005, Uezu et al. 2005). Generally, negative effects are characterized by population declines from increased mortality, changes in resource availability or nesting sites (Lopez de Casenave et al. 1998, Zanette and Jenkins 2000, Bennett 2003). Fragmentation may also alter bird community structure through reductions of forest interior species, followed by an increase of generalist species associated with edge habitats (Merriam and Wegner 1992). Further, the increased isolation of remnant forest patches may compromise movement of species with reduced dispersal ability with potential negative consequences when remnant forest patches are immersed in a matrix of unsuitable habitat (Lens et al. 2002, Şekercioglu et al. 2002). Consequently, spatial scale plays a prominent role in the response of bird species to fragmentation (Holland and Bennett 2009).

The spatial scales at which birds respond to environmental characteristics may have conservation and management implications (Holland and Bennett 2009). For example, within patch, i.e., tree density and height, and patch-scale, i.e., patch size, features have been linked to population abundance and community structure of forest birds (Forman 2006, Skórka et al. 2016). Alternatively, factors characterizing the surrounding matrix can determine the main effects on bird community structure and composition (Gascon et al. 1999, Ribic and Sample 2001, Horn and Koford 2006). These hierarchal, i.e., patch to landscape, responses reflect the various environmental components required by forest birds to maximize fitness and complete their annual cycle (Manning et al. 2004, Thornton et al. 2011). Assessing the degree of sensitivity or tolerance at patch and landscape scales can provide insight into the effects of agriculture expansion on native forest birds. If we compare and integrate agricultural landscapes that represent a gradient of changes that occurred during the fragmentation process, trading space for time, we can determine bird response to agricultural expansion (dos Anjos 2006, Şekercioglu and Sodhi 2007).

Agricultural expansion is expected to continue in the province of Entre Ríos with consequent alterations to native forest cover and configuration. Therefore, it is important to assess the influence of this multiscale process on one of the better indicators of ecological conditions, namely, native forest birds (Canterbury et al. 2000, O'Connell et al. 2000). In this study we analyzed the effect of forest fragmentation at patch and landscape scales on birds in east-central Argentina. Our objectives were to examine relationships between relative abundance of birds and environmental characteristics at patch and landscape scales and identify predictor variables influencing bird abundance. We predicted response by native forest birds to fragmentation in our study landscape would be a function of degree of habitat specialization and would differ by individual species along an autoecological gradient from sensitive to tolerant. Further, we predicted relative abundance of forest bird species would reflect variability of site-specific differences in patch characteristics. We used predictive habitat models to relate bird abundance to environmental characteristics of fragmented forest landscapes to assess their use for conservation planning (Mazerolle and Villard 1999, Henle et al. 2004, Thornton et al. 2011).

\section{METHODS}

\section{Study area}

We conducted our study in the departments of Paraná, Diamante, Nogoyá, and La Paz of Entre Ríos province located in eastern Argentina. Entre Ríos is found within the Espinal ecoregion (Cabrera 1994). The Espinal ecoregion is characterized by semixerophytic forests dominated by hardwood tree species such as Prosopis affinis, Acacia caven, Geoffroea decorticans, and Celtis ehrenbergiana (Lewis et al. 2009, Matteucci 2012). Mean annual temperature is $18-20^{\circ} \mathrm{C}$ and precipitation ranges from 800 to 1000 $\mathrm{mm}$. Topography of the landscape is mostly flat plains interspersed with smooth undulations. The current state of Espinal forest remnants is the outcome of a process of secondary succession. Anthropogenic disturbances originated by indigenous peoples approximately 2000 years ago, but deforestation substantially intensified during the last 200 years. The most important changes in vegetation have occurred since the beginning of the 20th century, mainly from cattle ranching followed by industrial agriculture, mostly soybean (Muñoz et al. 2005, Engler and Vicente 2009, Matteucci 2012).

We placed a grid with a cell size of $30 \times 30 \mathrm{~km}$ in each of the provincial departments encompassing our study area using a Geographic Information System. We classified all cells, using visual interpretation, according to the proportion of native forest cover into three categories $(>50 \%, 15-50 \%,<5 \%$ ), then randomly selected one cell for each category. The selected landscape mosaics represented a gradient of forest fragmentation resulting from agricultural expansion processes (Fig. 1). Mosaic I (31 20'31.5" S, $59^{\circ} 26^{\prime} 43.2^{\prime \prime} \mathrm{W}$ ) included $54 \%$ native forest cover interspersed with agricultural patches. Mosaic II (31³4'52.2" S, 6004'29.3" W) was dominated by an agricultural matrix with $23 \%$ forest cover connected by corridors of riparian forest. Finally, mosaic III $\left(32^{\circ}\right.$ 
02'2.6" S, 60²'18'29.9" W) was dominated by intensive crop agriculture with interspersed forest fragments representing $4 \%$ of the total area.

Fig. 1. Map of Argentina indicating location of Entre Ríos province and study mosaics. Detail of sublandscape with highlighted forest patch (dark green areas) and outline of bird sampling points within forest patch.

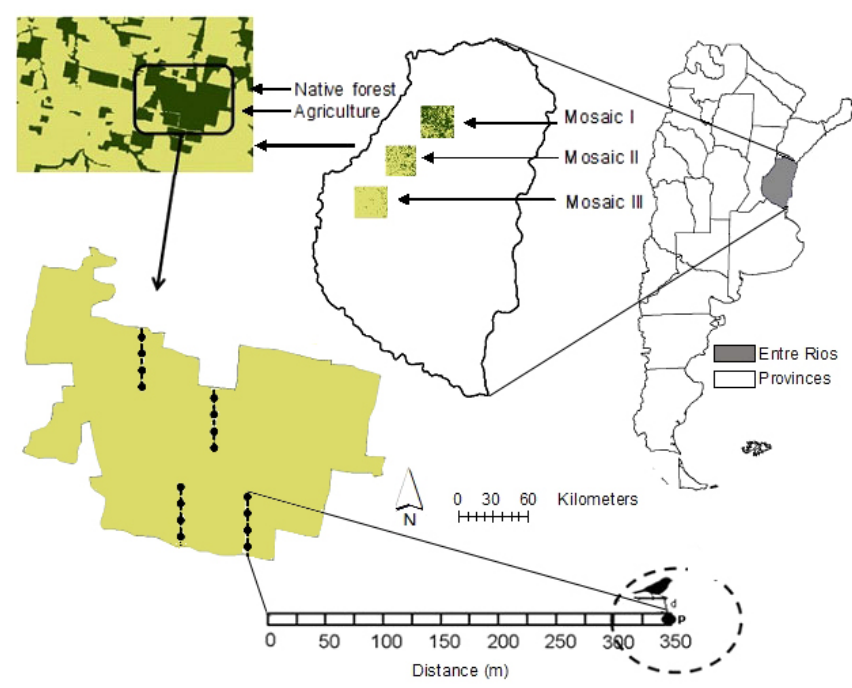

Each landscape mosaic was subdivided into nine nonoverlapping $10 \times 10 \mathrm{~km}$ cells using ArcGIS version 9.2 (Esri, Redlands, CA, USA). We randomly selected six cells, hereafter termed sublandscapes. Within each sublandscape we randomly selected forest patches in three size categories $(<7$ ha, $8-20$ ha, $>21$ ha), 15 in each mosaic for a total of 45 patches. A forest patch was defined as a contiguous area covered by native forest that differed from its surroundings. Average size of these 45 native forest patches ( \pm standard error) was $37.16 \pm 5.25$ ha. However, mean patch area was 253.95 ( \pm 40.03), 64.36 ( \pm 12.85$)$, and 15.12 $( \pm 4.19)$ for mosaics I, II, and III, respectively. Following a first visit to each patch, we planned our bird and vegetation structure sampling scheme.

\section{Bird community}

We sampled forest birds during the austral seasons of fall-winter 2007 and 2008 (May to July) and spring-summer 2007-2009 (November to January). We selected 19 diurnal, terrestrial bird species to derive abundance estimates (Table A1.1). Selected taxa were common species representative of the Espinal forest region (Narosky and Yzurieta 2010). Further, selected species illustrated a diversity of foraging guilds, e.g., insectivores and granivores, and habitat use preferences of varying forest strata (understory, midstory, canopy). Common and taxonomic names of bird species followed De la Peña and Rumboll (1998).

We used 10-minute circular point counts (50-m radius) to estimate relative abundance, expressed as number of birds per point per patch (Savard and Hooper 1995, Bibby et al. 2000). We randomized distance between transects and placed points along transects perpendicular to the edge of each forest patch. The number of points on a given transect was proportional to patch size (range $=4-16$ points per patch) and points were located at a minimum distance of $100 \mathrm{~m}$ to decrease the possibility of double counting (Bibby et al. 2000; Fig. 1). Surveys were conducted between 0600-1000 h (spring-summer), 0700-1100 h (fall-winter) or 1500-1900 h (spring-summer), 1400-1800 h (fall-winter), with one patch sampled per morning-afternoon period. We visited each point once per season. Surveys were not conducted during rainy or windy days (wind $\geq 20 \mathrm{~km} / \mathrm{h}$ ). During the first set of surveys, the number of observations was greater in the morning block $(=253, \mathrm{SE}=69.30)$ compared to the afternoon $(=181, \mathrm{SE}$ $=29.79$ ). Therefore, we kept the same block observation in the first two surveys and reversed the block schedule in the last two surveys. This decision was made to avoid masking possible seasonal influences on bird detections (Bibby et al. 2000). We attempted to estimate detection functions for all bird species in native forest patches based on distance data and following Buckland et al. (2001). However, for most species this approach was not feasible primarily because of an insufficient number of independent detections to fit the detection function, thus violating a key assumption of distance sampling. Therefore, abundance estimates were reported as relative abundance \pm standard error.

\section{Patch-scale variables}

We selected vegetation structure variables to measure characteristics within forest patches based on the literature (García Del Rey and Cresswell 2005, Johnston and Holberton 2009). We used the dot-quadrant method (Cottam and Curtis 1956) at each point to quantify tree density (D_Arb) and shrub density (D_arb) as number of trees/shrubs per hectare. We also documented additional measures collected from the tree closest to the center of the plot in each quadrant, including tree height (A_Arb) using a clinometer (Romahn de la Vega et al. 1994), and diameter at breast height (DBH). These measures were averaged over all sampling points in a patch to obtain a single value representing patch scale vegetation structural variables.

We considered additional patch level variables known to affect bird populations (i.e., breeding habitat), community structure, or spatial and temporal distribution (Estades 2001, Graham and Blake 2001, Suarez-Rubio and Thomlinson 2009). These included patch area (PA), total edge (TE), shape index (SI), perimeter-area ratio (PARA), fractal dimension (FD), linear distance of patch to nearest settlement (DistLoc), latitude (X), and longitude (Y) for the central point of each forest patch (Gauss-Kruger, zone 5). The last two variables were included in the analysis to account for potential landscape scale spatial patterns masking relationships between bird abundance and patch characteristics, and account for potential correlation of other variables responding to the same landscape scale gradients.

Variables were measured using Quickbird images (available in Google Earth ${ }^{\mathrm{TM}}$ http://earth.google.com) and the Patch Analyst extension for ArcGIS (Rempel et al. 2012). These described the amount and configuration of each forest patch beyond those that described environmental characteristics within patches. Possible correlations among patch scale variables were tested using a Pearson's matrix and discarded variables that showed high levels of correlation $(\mathrm{r} \geq 0.70, \mathrm{P}<0.05$; Table 1$)$. 
Table 1. Correlation matrix for forest patch scale variables. D_Arb = Density of trees, D_arb = Density of shrubs, A_Arb = Tree height, $\mathrm{DBH}=$ Diameter at breast height, $\mathrm{PA}=$ Forest patch area, $\mathrm{TE}=$ Total edge, $\mathrm{SI}=$ Shape index, PARA $=$ Perimeter-area ratio, FD $=$ Fractal dimension, DistLoc $=$ Lineal distance from forest patch to nearest settlement.

\begin{tabular}{|c|c|c|c|c|c|c|c|c|c|c|c|}
\hline & D_Arb & D_arb & A_Arb & DBH & DistLoc & $\mathrm{X}^{\dagger}$ & $\mathrm{Y}^{*}$ & PA & TE & SI & PARA \\
\hline \multicolumn{12}{|l|}{ D_Arb } \\
\hline D_arb & 0.23 & & & & & & & & & & \\
\hline A_Arb & 0.25 & -0.12 & & & & & & & & & \\
\hline DBH & 0.03 & -0.22 & 0.63 & & & & & & & & \\
\hline DistLoc & -0.12 & -0.15 & -0.35 & -0.01 & & & & & & & \\
\hline X & 0.28 & 0.26 & -0.28 & -0.08 & 0.26 & & & & & & \\
\hline Y & 0.52 & 0.30 & -0.10 & 0.05 & 0.20 & $0.89^{*}$ & & & & & \\
\hline PA & 0.14 & 0.35 & 0.12 & -0.10 & -0.23 & 0.01 & 0.03 & & & & \\
\hline TE & 0.04 & 0.29 & 0.17 & -0.06 & -0.19 & -0.15 & -0.13 & $0.89^{*}$ & & & \\
\hline SI & -0.22 & 0.02 & 0.17 & 0.02 & -0.05 & -0.39 & -0.36 & 0.34 & $0.70^{*}$ & & \\
\hline PARA & -0.24 & -0.27 & -0.12 & 0.11 & 0.26 & 0.01 & 0.01 & -0.67 & -0.63 & -0.08 & \\
\hline FD & -0.37 & -0.26 & 0.03 & 0.11 & 0.18 & -0.32 & -0.30 & -0.40 & -0.10 & 0.60 & $0.72^{*}$ \\
\hline \multicolumn{12}{|c|}{$\begin{array}{l}* \mathrm{P}=0.05 \\
\mathrm{X}^{\dagger}=\text { latitude } \\
\mathrm{Y}^{*}=\text { longitude }\end{array}$} \\
\hline
\end{tabular}

\section{Landscape-scale variables}

We quantified amount and spatial configuration of forest cover in each sublandscape using reference satellite images (Landsat Thematic Mapper, 5) of 30-m spatial resolution (Path 226-Row 82, January 2007-2008). Images were downloaded from the Brazilian National Institute for Space Research (INPE) web site. Thermal bands were not retained because of coarser resolution. Images were geometrically corrected using a first-degree polynomial model given study area topography. Images were orthorectified using a digital elevation model (DEM, 30-m spatial resolution) and nearest neighbor as a resampling method. Vector topology was reconstructed using a PAEK algorithm (polynomial approximation with exponential Kernel) with a $50 \mathrm{~m}$ tolerance (Menéndez and La Roca 2007), then vectors rasterized (5-m cell size) in ArcGIS.

Landsat ${ }^{\mathrm{TM}}$ satellite images were classified with support vector machines (SVM), a nonparametric supervised classification algorithm (van der Linden et al. 2009). The SVM approach distinguishes classes by fitting separating hyperplanes in feature space based on training samples (Foody and Mathur 2004). After training sites were digitized, statistical characterizations were derived and 10 land use-cover types identified: water bodies (W), corn (C), sunflower (S), soybean (S), sorghum (So), other crops (Oc) included annual and perennial pastures and fields with weeds, introduced forest (Pf), native forest (Fn), flooded vegetation (Vf) and urban-bare soil (URS).

We trained the SVM using 250 randomly selected pixels of each class. Although the SVM approach was originally developed for binary classifications, we worked with multiclass images overcoming that problem through a one-against-one approach that applied a set of individual classifiers to all possible class pairs and performed a majority vote to assign the winning class (Huang et al. 2002, Pal and Mather 2005). Further, we determined magnitude of penalty given to misclassified training data $(C)$ and width of the Gaussian kernel function selected $(\gamma)$. Once optimal parameters were found, we used the resulting SVM to classify the images (Janz et al. 2007, Kuemmerle et al. 2008). We eliminated pixel groups smaller than 0.81 ha $(3 \times 3$ pixels) representing classification artifacts or areas without ecological importance to the scale of our study. We validated classification results with 100 randomly selected points per land class type using Quickbird images and ground truthing (Congalton and Green 2009). Overall classification accuracy was $82 \%$ (2007) and 84\% (2008; Table A2.1).

We estimated forest fragmentation in each sublandscape by calculating metrics that quantified amount and edge of forest cover, namely total forest area in each mosaic (FA, A3.1), number of forest patches (NP, A3.2), mean patch area (PA, A3.3), and edge density (ED, A3.4). Additionally these metrics described shape complexity of forest patches with measures of shape index (SI, A3.5), fractal dimension index (FD, A3.6), and perimeterarea ratio (PARA, A3.7). Finally, they addressed spatial configuration of the forest via mean distance (Euclidean) to nearest neighbor patch (ENN, A3.8), patch cohesion index $(\mathrm{COH}$, A3.9), and aggregation index (AI, A3.10). These are considered robust metrics for fragmentation measurements and allow the definition of patterns (Wang et al. 2014). When constructing our models, we averaged metrics for 2007 and 2008 as there was no difference among years $(\mathrm{P}>0.05)$. We used area of each cover type, contagion (CO), interspersion and juxtaposition (IJI), and richness (PR) to characterize the surrounding matrix on each sublandscape. All landscape-scale metrics were calculated using FRAGSTATS version 4 (McGarigal et al. 2012).

\section{Analysis}

We used Kruskal Wallis tests $(\mathrm{P}>0.05)$ to evaluate differences at patch and landscape scale variables between mosaics. The relationships between the environmental metrics selected to characterize forest patches indicated variables PA and TE were highly correlated (Table 1). Therefore, we selected PA for model building given its wide use in other studies of species-habitat relationships (Munguía-Rosas and Montiel 2014). Variables describing forest patches PARA and FD were also strongly correlated. Therefore, we included only FD in our models because this index reflects shape complexity across a range of spatial scales 
(patch sizes; McGarigal et al. 2012; Table 1). We discarded X and $\mathrm{Y}$ given these were autocorrelated, although were uncorrelated with any of the other explanatory variables. Therefore, this discards any possible spatial patterns of patch scale variables along the landscape fragmentation gradient. Further, we used a correlation approach to examine relations among cover type metrics at the landscape scale. Because forest cover landscape metrics were correlated ( $\mathrm{r} \geq 0.70, \mathrm{P}<0.05$; Table 2$)$, we used a principal components analysis (PCA) to obtain independent measurements of these variables (McCune et al. 2002). The resulting two vectors accounted for $86 \%$ of the variance in the original data matrix (PC1 63\%, PC2 23\%). Axis PC1 represented a gradient of sublandscapes dominated by large patches of connected forest with less edge and simpler shapes to sublandscapes with reduced forest cover characterized by smaller patches of forest with greater edge and complex shapes. Axis PC2 represented a gradient of covariation among sublandscapes with low number of large patches to sublandscapes with greater number of smaller patches and finally, sublandscapes characterized by low patch number of small size.

Table 2. Correlation matrix of spatial metrics for amount and spatial configuration of forest cover of sublandscapes $(10 \times 10$ $\mathrm{km}) . \mathrm{FA}=$ Total forest area (ha), NP $=$ Number of patches, ED $=$ Edge density, $\mathrm{PA}=$ Mean patch area, $\mathrm{SI}=$ Shape index, $\mathrm{FD}=$ Fractal dimension, PARA $=$ Area-perimeter ratio, ENN $=$ Mean euclidean nearest neighbor patch distance, $\mathrm{COH}=$ Patch cohesion index, $\mathrm{AI}=$ Aggregation index.

\begin{tabular}{lccccccccc}
\hline \hline & FA & NP & ED & PA & SI & FD & PARA & ENN & COH \\
\hline NP & 0.09 & & & & & & & & \\
ED & $0.84^{*}$ & 0.49 & & & & & & & \\
PA & $0.94^{*}$ & -0.14 & $0.71^{*}$ & & & & & & \\
SI & -0.62 & -0.63 & $-0.79^{*}$ & -0.48 & & & & & \\
FD & $-0.71^{*}$ & -0.53 & $-0.83^{*}$ & -0.58 & $0.92^{*}$ & & & & \\
PARA & 0.53 & -0.43 & 0.14 & $0.70^{*}$ & 0.06 & 0.00 & & & \\
ENN & -0.50 & -0.50 & -0.68 & -0.40 & $0.85^{*}$ & 0.63 & 0.11 & & \\
COH & $0.81^{*}$ & 0.27 & $0.90^{*}$ & $0.70^{*}$ & -0.65 & $-0.73^{*}$ & 0.20 & -0.60 & \\
AI & 0.62 & 0.53 & $0.79^{*}$ & 0.50 & $-0.92^{*}$ & $-0.78^{*}$ & -0.06 & $-0.96^{*}$ & $0.75^{*}$ \\
\hline
\end{tabular}

Relative abundance of each bird species per season was modeled as a function of patch and landscape variables. We built two sets of models independently. These included models where patch variables were considered, and models with landscape variables only. We selected this approach given differences in sample sizes, with 45 patches for the first set of models and 18 (six sublandscapes in each of three mosaics) at the landscape scale. Based on this criterion, each model included only one to three explanatory variables.

The response variable (relative bird abundance) and explanatory variables (patch and landscape metrics) were examined graphically and analytically for multicollinearity and deviation from normality using Infostat (Di Rienzo et al. 2010). We then used generalized linear models (GLM; Guisan et al. 2002, Seavy et al. 2005) with a Gaussian error structure (log-transformed when condition was not met) to examine the influence of environmental variables on relative abundance of each bird species using package glm in program $\mathrm{R}$ ver.2.14 (R Development Core Team 2013). We first constructed models for each single variable, followed by models with sets of two and three variables within each model set (Table A4.1). We used this exploratory approach, rather than a more restricted set of a prior models (Fletcher and Koford 2002) given the absence of prior information on the explanatory power of our variables. We used Akaike's information criteria adjusted for small sample size (AICc) to compare model performance and considered $\triangle$ AICc scores $\leq 2$ to be competitive models (Burnham and Anderson 2002).

For each spatial scale analyzed we used model averaging and sum of weights of competitive models where a variable was present ( $\sum \omega \mathrm{i}$; Burnham and Anderson 2002) to evaluate individual variable performance at each scale (patch and landscape). Variables with a value of $\Sigma \omega$ i close to 1 were the most important predictor variables. Additionally, we used a hierarchical partitioning analysis to calculate the percent variance of the full model explained by each variable when all other variables were included in the model. For estimates of avian abundance, we fitted all possible models based on different combinations of the explanatory variables. For each fitted model the variable of interest was removed before refitting the model. Variable importance was calculated as the average change in $\mathrm{R}^{2}$ when a variable was removed from all fitted models (MacNally 2002). Finally, we assessed spatial autocorrelation using randomized semivariograms of model residuals (Isaaks and Srivastava 1989). There was no evidence of a spatial autocorrelation effect in our models.

\section{RESULTS}

\section{Bird species abundance}

We removed Greyish Saltator (Saltator coerulescens) and Shortbilled Canastero (Asthenes baeri), from subsequent analysis because of the low number of detections. Relative abundance estimates differed for most species by season (fall-winter, springsummer) and landscape mosaic (Fig. 2). Picui Ground Dove (Columbina picui) and Monk Parakeet (Myiopsitta monachus) were the most abundant species in forest patches. Relative abundance of Picui Ground Dove was $1.24 \pm 0.21$ individuals per point per patch during fall-winter and $1.47 \pm 0.25$ per point per patch during spring-summer. Monk Parakeet relative abundance was $1.34 \pm 0.21$ per point per patch in fall-winter, and $1.45 \pm 0.25$ per point per patch in spring-summer.

Mosaic I, characterized by the greater amount of forest cover, contained greater abundances of Scimitar-billed Woodcreeper (Drymornis bridgesii), Creamy-bellied Thrush (Turdus amaurochalinus), Red-crested Cardinal (Paroaria coronata), Suiriri Flycatcher (Suiriri suiriri), and Black-capped Warbling Finch (Poospiza melanoleuca). Conversely, Great Antshrike (Taraba major) and Narrow-billed Woodcreeper (Lepidocolaptes angustirostris) were more abundant in mosaic II, while the most abundant species in mosaic III included Picui Ground Dove, Grayish Baywing (Agelaioides badius), Saffron Finch (Sicalis flaveola), and Masked Gnatcatcher (Polioptila dumicola; Fig. 2).

\section{Mosaic description}

As expected, tree density was greater in mosaic I ( $=355 \pm 36$ indiv/ ha) and mosaic II ( $=451 \pm 25$ indiv/ha) compared with mosaic III ( = $166 \pm 29$ indiv/ha, Table A5.1). However, tree height was greater and statistically significant only in mosaic II $(=5.40 \pm 0.18$ 
Fig. 2. Relative abundance (no. indiv/point/patch) of birds in forest patches sampled in landscape mosaics of Entre Ríos province, Argentina, during fall-winter (black) and spring-summer (gray) of 2007-2008.
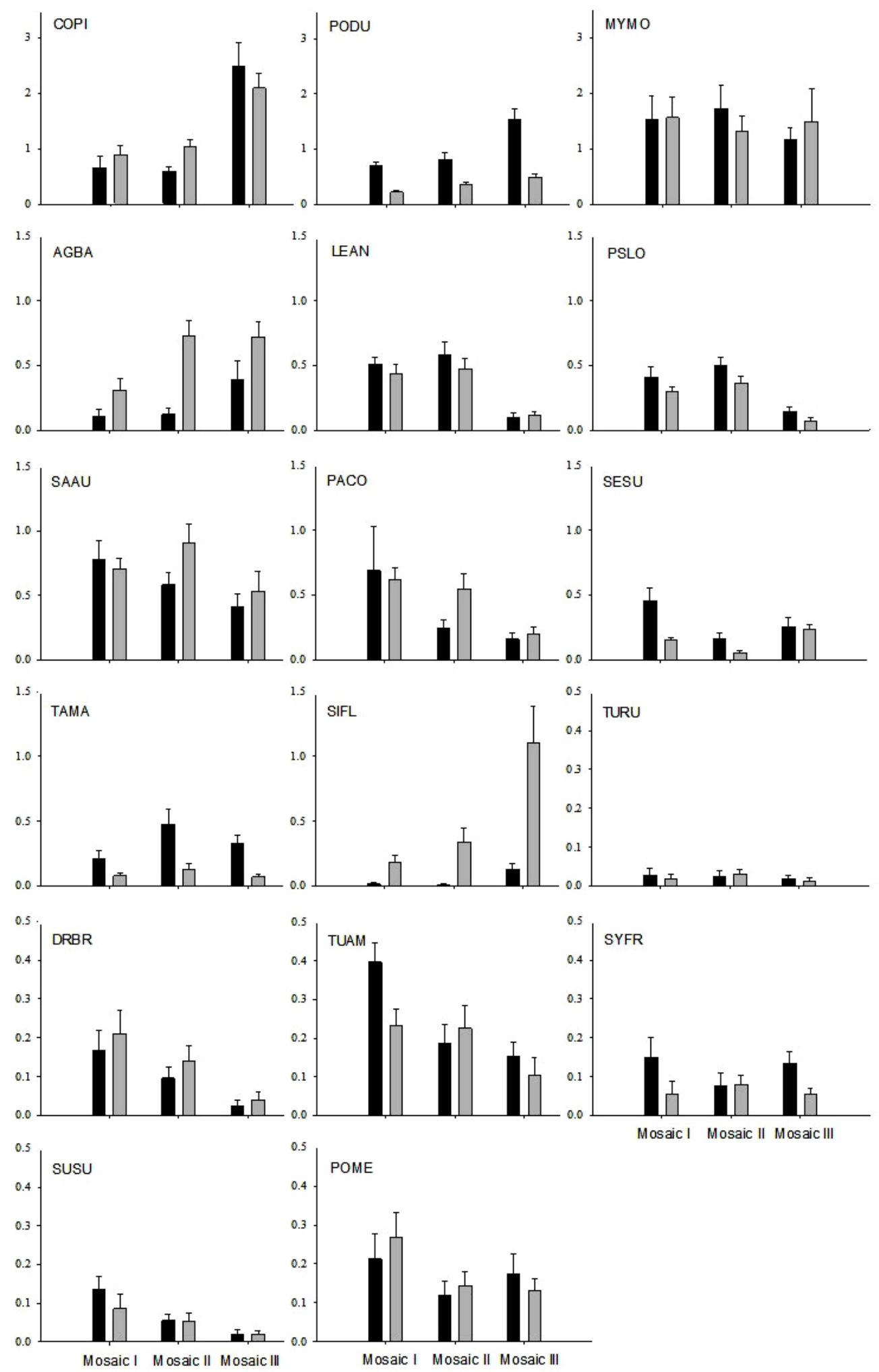
m) compared with mosaic I ( $=4.44 \pm 0.18 \mathrm{~m})$. Shrub density did not differ between mosaics (mosaic $\mathrm{I}=528 \pm 84$ indiv/ha, mosaic $\mathrm{II}=462 \pm 79 \mathrm{indiv} / \mathrm{ha}$ and mosaic III $=289 \pm 44 \mathrm{indiv} / \mathrm{ha}$ ). Forest amount and configuration differed $(\mathrm{P}<0.05)$ between mosaics. Mosaic I was dominated by continuous forest cover while mosaic III had the lowest amount of forest (Table A5.1). Mosaic I was mainly characterized by $54 \%$ native forest, $38 \%$ annual crops, whereas mosaic II had 23\% native forest, $66 \%$ annual crops, and finally mosaic III had 4\% native forest and 77\% annual crops. Additionally, mosaic II had the greater number of forest patches indicating an intermediate stage in the fragmentation process, whereas mosaic III had the lowest number of patches; its mean area was also the lowest and its mean shape of patches was the most complex (Table A5.1).

We observed that some variables presented associations among spatial scales, despite evaluating relationships between bird abundance and environmental metrics at both patch and landscape scales using independent sets of models (Table A6.1). On the one hand, these associations indicated that patches with greater tree height were found in landscapes characterized by a greater number of patches. On the other hand, the shape complexity of the 45 sampled patches was positively associated with the shape pattern at landscape scale. Finally, the landscapes characterized by greater number of forest patches (included in axis PC2) were also characterized by the more disaggregated land use-cover types (Table A6.1).

\section{Patch and landscape scales bird response}

Although the response to forest fragmentation varied among avian species, we identified two main patterns: (1) species sensitive to vegetation structure conditions within patch and forest fragmentation (e.g., Narrow-billed Woodcreeper, Scimitar-billed Woodcreeper, and Brown Cacholote (Pseudoseisura lophotes), and (2) tolerant species (e.g., Picui Ground Dove, Saffron Finch, and Masked Gnatcatcher).

Vegetation structural variables were incorporated in most individual bird models (Table 3). Number of trees per hectare was important when determining abundance of bird species during both seasons. Variables related to tree size (DBH and A_Arb) were not as important as tree density (Table 4). Tree height had a strong and positive effect on several species including Sootyfronted Spinetail (Synallaxis frontalis), Great Antshrike, Creamybellied Thrush, Golden-billed Saltator (Saltator aurantiirostris) and a negative effect on White-crested Tyrannulet (Serpophaga subcristata), Saffron Finch, and Monk Parakeet. Shrub density had a clear negative effect on only three species; Rufous-bellied Thrush (Turdus rufiventris), Grayish Baywing, and Picui Ground Dove. The abundance of Narrow-billed Woodcreeper, Scimitarbilled Woodcreeper, Great Antshrike, and Creamy-bellied Thrush increased proportionally with density of trees within forest patches. Conversely, Grayish Baywing, Picui Ground Dove, Black-capped Warbling Finch, and Saffron Finch were more abundant in patches with lesser tree densities (Table 3).

Variables characterizing patch shape complexity, such as shape index (SI) and fractal dimension (FD) were incorporated in most individual bird models during both seasons (Table 3). Furthermore, relative importance based on model weights of SI (range $=0.28-0.98)$ and FD (range $=0.24-1.00)$ was greater for most bird species (Table 4). For example, Scimitar-billed Woodcreeper, Narrow-billed Woodcreeper, Grayish Baywing, Red-crested Cardinal, and Brown Cacholote were more abundant in patches of simpler shape and lesser ratio of edge to forest interior. Conversely, Picui Ground Dove, Great Antshrike, Saffron Finch, Sooty-fronted Spinetail, Masked Gnatcatcher, and Golden-billed Saltator were more abundant in patches of greater shape complexity and greater ratio of edge to forest interior. Proximity to population settlements did not have a clear effect on any bird species, except for Monk Parakeet that was clearly favored by closeness to settlements (Table 3).

Birds also responded to amount and spatial configuration of forest at landscape scale as forest fragmentation metrics were present in the best models (Table 3 ). Variables summarized by PC1 exhibited greater mean relative importance (0.68) than variables summarized by PC2 (0.41; Table 4). Furthermore, PC1 was found in most species landscape scale models. The relationship of individual bird species to PC1 varied depending on their affinity to forest habitat, ranging from species that feed, reproduce, and nest within the forest, i.e., forest specialists, to open habitat generalists that use the forest, but also the surrounding matrix. Conversely, PC2 was selected in a smaller number of models, some of these included bird species that exhibited a positive response to landscapes with greater number of patches of native forest, e.g., Grayish Baywing, Great Antshrike, and Rufous-bellied Thrush, while other species such as Black-capped Warbling Finch, Creamy-bellied Thrush, Whitecrested Tyranulet, and Monk Parakeet responded negatively (Table 3).

Finally, the surrounding matrix influenced many bird species such as the Golden-billed Saltator, who exhibited a positive effect of interspersion and juxtaposition (IJI), and whose abundance was greater in landscapes where patch types were close together. Conversely, other species were negatively influenced by IJI including the Scimitar-billed Woodcreeper and White-crested Tyranulet (Table 3). On the other hand, abundance of Rufousbellied Thrush and Monk Parakeet was positively associated to contagion, and was greater in landscapes where all patch types were aggregated, while Narrow-billed Woodcreeper, Sootyfronted Spinetail, and Creamy-bellied Thrush had a negative response to $\mathrm{CO}$ (Table 3). Finally, the abundance of Grayish Baywing, Red-crested Cardinal, and Brown Cacholote was greater in landscapes with fewer types of different land use-cover (PR; Table 3). Nevertheless, relative importance ( $\left.\sum \omega \mathrm{i}\right)$ of landscape predictor variables describing the matrix was low $(<$ 0.5 ; Table 4).

\section{DISCUSSION}

Forest structure, amount, and spatial configuration successfully explained patterns of bird abundance in fragmented landscapes of the Espinal region in east-central Argentina. Although some species exhibited no apparent response or a positive response to fragmentation, a subset of bird species responded negatively to these patterns at both patch and landscape scales. Thus, potential changes in bird communities in east-central Argentina could be driven by reduced abundance of forest sensitive species. This in turn may enhance the potential for population declines, including local extinctions, as landscapes become increasingly fragmented and simplified (Boulinier et al. 2001). These results were 
Table 3. Best generalized linear models describing bird abundance in forest patches during the austral fall-winter and spring summer, in the province of Entre Ríos, Argentina. Parentheses indicate a negative relationship to bird abundance.

\begin{tabular}{|c|c|c|c|c|c|c|c|}
\hline \multirow[t]{2}{*}{ Species $^{\dagger}$} & \multirow[t]{2}{*}{ Season $^{*}$} & \multicolumn{6}{|c|}{ Model } \\
\hline & & $\operatorname{Patch}^{\S}$ & $\mathrm{AICc}$ & Akaike weight ( $\omega$ i) & Landscape & $\mathrm{AICc}$ & Akaike weight (wi) \\
\hline \multirow{2}{*}{ COPI } & FW & $\left(-D \_A r b\right)+\left(-D \_a r b\right)$ & 117.46 & 0.36 & $\mathrm{PC} 1$ & 30.52 & 0.37 \\
\hline & SS & $\left(-D \_A r b\right)+\left(-D \_a r b\right)$ & 114.42 & 0.28 & PC1 & 40.33 & 0.27 \\
\hline \multirow[t]{2}{*}{ AGBA } & FW & (-D_Arb) & 112.09 & 0.32 & $(-\mathrm{PR})$ & 42.27 & 0.32 \\
\hline & SS & (-D_arb) & 61.92 & 0.36 & $\mathrm{PC} 2+(-\mathrm{PR})$ & 13.54 & 0.20 \\
\hline \multirow[t]{2}{*}{ DRBR } & FW & $(-\mathrm{SI})$ & -47.41 & 0.57 & $(-\mathrm{PCl})+(-\mathrm{IJI})$ & -40.63 & 0.49 \\
\hline & SS & $(-\mathrm{SI})+(-\mathrm{DF})+$ D_Arb & -27.78 & 0.38 & $(-\mathrm{PC} 1)$ & -24.19 & 0.19 \\
\hline \multirow[t]{2}{*}{ LEAN } & FW & D_Arb $+(-\mathrm{SI})+(-\mathrm{FD})$ & 13.95 & 0.39 & $(-\mathrm{PC} 1)+(-\mathrm{CO})$ & 1.41 & 0.44 \\
\hline & SS & D_Arb + DBH & 6.80 & 0.69 & $(-\mathrm{PC} 1)+(-\mathrm{CO})$ & -2.54 & 0.50 \\
\hline \multirow[t]{2}{*}{ SYFR } & FW & FD + A_Arb & -51.00 & 0.77 & PR & -23.83 & 0.16 \\
\hline & SS & FD + A_Arb & 46.46 & 0.57 & $(-\mathrm{CO})$ & 12.94 & 0.20 \\
\hline \multirow[t]{2}{*}{ PSLO } & FW & $(-\mathrm{SI})$ & 12.52 & 0.49 & $(-\mathrm{PC} 1)+(-\mathrm{PR})$ & -4.89 & 0.31 \\
\hline & SS & D_Arb $+(-S I)+(-F D)$ & -15.81 & 0.26 & $(-\mathrm{PC} 1)$ & -13.45 & 0.37 \\
\hline \multirow[t]{2}{*}{ TAMA } & FW & D_Arb + A_Arb + SI & 20.25 & 0.52 & PC2 & 8.95 & 0.21 \\
\hline & SS & D_Arb + A_Arb + SI & -75.22 & 0.78 & PC2 & -34.65 & 0.15 \\
\hline \multirow[t]{2}{*}{ PODU } & FW & $\left(-\overline{\mathrm{D}} \_\mathrm{Arb}\right){ }^{-}$ & 83.37 & 0.37 & PC1 & 12.33 & 0.34 \\
\hline & SS & (-D_Arb) & -6.24 & 0.61 & $\mathrm{PC} 1$ & -20.03 & 0.33 \\
\hline \multirow[t]{2}{*}{ TURU } & FW & $\left(-D \_a r b\right)+D \_A r b$ & -127.47 & 0.56 & $\mathrm{PC} 2+\mathrm{CO}$ & -9.97 & 0.27 \\
\hline & SS & D_Arb & -153.84 & 0.39 & $\mathrm{PC} 2+\mathrm{CO}$ & -71.88 & 0.23 \\
\hline \multirow[t]{2}{*}{ TUAM } & FW & DistLoc & -13.30 & 0.34 & $(-\mathrm{PC} 1)+(-\mathrm{PC} 2)$ & -24.22 & 0.47 \\
\hline & SS & A_Arb $+(-D B H)$ & -18.31 & 0.32 & $(-\mathrm{PC} 1)+(-\mathrm{CO})$ & -14.38 & 0.30 \\
\hline \multirow[t]{2}{*}{ SAAU } & FW & D_Arb + A_Arb & 63.45 & 0.26 & $(-\mathrm{PC} 1)+\mathrm{IJI}$ & 15.80 & 0.31 \\
\hline & SS & D_Arb + A_Arb + (-DBH) & 60.85 & 0.32 & $(-\mathrm{PC} 1)+\mathrm{IJI}$ & 21.72 & 0.33 \\
\hline \multirow[t]{2}{*}{ PACO } & FW & $(-\overline{\mathrm{SI}})$ & 118.48 & 0.34 & $(-\mathrm{PC} 1)$ & 34.75 & 0.33 \\
\hline & SS & $(-\mathrm{SI})$ & 43.38 & 0.51 & $(-\mathrm{PC} 1)+(-\mathrm{PR})$ & 3.97 & 090 \\
\hline \multirow[t]{2}{*}{ POME } & FW & $\left(-\mathrm{D} \_\mathrm{Arb}\right)+(-\mathrm{DBH})$ & -19.70 & 0.91 & $(-\mathrm{PC} 2)$ & -16.02 & 020 \\
\hline & SS & $\mathrm{PA}+(-\mathrm{SI})+\mathrm{FD}$ & -33.21 & 0.98 & $(-\mathrm{PC} 1)$ & -20.01 & 025 \\
\hline \multirow[t]{2}{*}{ SUSU } & FW & $(-F D)$ & -88.69 & 0.57 & $(-\mathrm{PCl})$ & -45.33 & 0.32 \\
\hline & SS & $\mathrm{PA}+(-\mathrm{FD})$ & 44.09 & 0.45 & $(-\mathrm{PC} 1)$ & 6.47 & 0.15 \\
\hline \multirow[t]{2}{*}{ SESU } & FW & (-A_Arb) & 15.32 & 0.48 & $(-\mathrm{IJI})$ & -6.50 & 0.24 \\
\hline & SS & (-D_Arb) & -55.90 & 0.48 & $\mathrm{PC} 1+(-\mathrm{PC} 2)$ & -39.13 & 0.81 \\
\hline \multirow[t]{2}{*}{ SIFL } & FW & $\left(-D \_A r b\right)+\left(-A \_A r b\right)$ & 63.29 & 0.22 & $\mathrm{PC} 1$ & 14.59 & 0.31 \\
\hline & SS & $\left(-D \_A r b\right)+\left(-A \_A r b\right)+D B H$ & 114.85 & 0.38 & PC1 & 39.92 & 0.35 \\
\hline \multirow[t]{2}{*}{ MYMO } & FW & $\left(-\mathrm{A} \_\mathrm{Arb}\right)+\mathrm{DBH}$ & 161.96 & 0.41 & $\mathrm{CO}$ & 60.82 & 0.19 \\
\hline & SS & (-DistLoc) & 141.20 & 0.31 & $(-\mathrm{PC} 2)$ & 51.74 & 0.17 \\
\hline
\end{tabular}

${ }^{\dagger}$ Codes of bird species listed in Table A1.1.

${ }^{\dagger} \mathrm{FW}=$ fall-winter, $\mathrm{SS}=$ spring-summer.

${ }^{\S}$ Patch-scale variables: D_Arb $=$ density of trees, D_arb $=$ density of shrubs, A_Arb $=$ tree height, DBH $=$ diameter at breast height, PA $=$ patch area (ha), $\mathrm{SI}=$ Shape index, $\mathrm{FD}=$ fractal dimension, DistLoc $=$ linear distance $(\mathrm{m})$ to nearest settlement.

Landscape spatial configuration variables: $\mathrm{PC} 1=$ fragmentation gradient principal component, $\mathrm{PC} 2$ = fragmentation covariate principal component, $\mathrm{IJI}=$ interspersion and juxtaposition, $\mathrm{CO}=$ Contagion, and $\mathrm{PR}=$ cover type richness

consistent with other published reports (Gehring and Swihart 2003, Cunningham and Johnson 2006, Thornton et al. 2011) on avian responses to forest fragmentation. Additionally, our results highlighted the importance of evaluating species-habitat relationships at multiple, i.e., patch and landscape, scales because factors varied in importance depending on the spatial scale. For instance, at the patch scale, vegetation structure within patches was comparatively more important than patch shape and size, while at the landscape scale the amount and spatial configuration of native forest cover were comparatively more important than composition and configuration of all cover types present in the landscape.

Vegetation structure within patches was an important predictor for many species in our study, similarly to patterns reported for other regions of the world (Martin 1998, Forman 2006). Tree density within patches was strongly associated (positively or negatively) with 15 out of 17 bird species in our study during both fall-winter and spring-summer. Increased density of trees would benefit cavity nesting species like the Narrow-billed Woodcreeper and Scimitar-billed Woodcreeper by increasing the availability of potential nesting and foraging sites, suggesting these species may be associated to particular forest patch conditions (Nadkarni and Longino 1990, Berg et al. 1994, Cockle et al. 2012). Interestingly, these results differed from studies conducted in North America where an inverse relationship to tree density has been reported for cavity nesting birds (Flack 1976, Brawn 1988). Most North American cavity nesters are more abundant in mature forests dominated by larger trees (and lower tree density), probably because older forests tend to have more dead trees and dead branches on live trees where cavities may be excavated or utilized. Many other species are secondary cavity nesters and rely on abandoned woodpecker nests or natural cavities. In the Espinal forest, bird species that nest in tree cavities are secondary users, 
Table 4. Relative importance of spatial metrics at patch and landscape scales based on sum of model weights ( $\sum \omega \mathrm{i}$, for each predictor variable shows the sum of Akaike weights for all possible models in which the predictor variable was incorporated at each level) and hierarchical variance partitioning (HP, percent of variance of the full model explained by each variable) for bird species sampled during the austral fallwinter and spring-summer, in the province of Entre Ríos, Argentina.

\begin{tabular}{|c|c|c|c|c|c|c|c|c|c|c|c|c|c|c|c|c|c|c|c|c|c|c|c|c|c|c|c|}
\hline \multirow[t]{3}{*}{ Species $^{\dagger}$} & \multirow[t]{3}{*}{ Season $^{*}$} & \multicolumn{16}{|c|}{ Patch $^{\S}$} & \multicolumn{10}{|c|}{ Landscape } \\
\hline & & \multicolumn{2}{|c|}{ D_Arb } & \multicolumn{2}{|c|}{ D_arb } & \multicolumn{2}{|c|}{ A_Arb } & \multicolumn{2}{|c|}{$\mathrm{DBH}$} & \multicolumn{2}{|c|}{ PA } & \multicolumn{2}{|c|}{ SI } & \multicolumn{2}{|c|}{ FD } & \multicolumn{2}{|c|}{ DistLoc } & \multicolumn{2}{|c|}{ PC1 } & \multicolumn{2}{|c|}{$\mathrm{PC} 2$} & \multicolumn{2}{|c|}{ IJI } & \multicolumn{2}{|c|}{ Contagion } & & $\mathrm{R}$ \\
\hline & & $\sum \omega \mathrm{i}$ & HP & $\overline{\sum \omega \mathrm{i}}$ & HP & $\sum \omega \mathrm{i}$ & HP & $\sum \omega \mathrm{i}$ & $\overline{\mathrm{HP}}$ & $\overline{\sum \omega \mathrm{i}}$ & $\overline{\mathrm{HP}}$ & $\sum \omega \mathrm{i}$ & $\overline{\mathrm{HP}}$ & $\overline{\sum \omega \mathrm{i}}$ & HP & $\overline{\sum \omega \mathrm{i}}$ & HP & $\sum \omega \mathrm{i}$ & HP & $\overline{\Sigma \omega \mathrm{i}}$ & $\mathrm{HP}$ & $\sum \omega \mathrm{i}$ & $\mathrm{HP}$ & $\sum \omega \mathrm{i}$ & $\mathrm{HP}$ & $\sum \omega \mathrm{i}$ & HP \\
\hline COPI & FW & 1.0 & 47.0 & 0.5 & 16.6 & & & & & & & & & 0.3 & 9.0 & & & 0.9 & 64.1 & & & & & & & & \\
\hline & SS & 0.9 & 44.8 & 0.5 & 19.8 & & & & & & & & & 0.5 & 19.9 & & & 0.8 & 42.2 & & & & & & & & \\
\hline AGBA & FW & 1.0 & 68.4 & & & & & & & 0.2 & 3.7 & 0.3 & 7.0 & 0.3 & 4.5 & & & & & & & & & & & 0.3 & 58.7 \\
\hline & SS & 0.5 & 13.7 & 0.6 & 46.3 & & & & & & & & & & & & & & & 0.4 & 44.7 & & & & & 0.2 & 12.7 \\
\hline DRBR & FW & & & & & & & & & & & 1.0 & 37.6 & 0.4 & 29.2 & & & 0.5 & 44.6 & & & 0.5 & 17.0 & & & & \\
\hline & SS & 0.6 & 8.1 & & & 0.3 & 18.7 & 0.3 & 11.3 & & & 0.7 & 14.0 & 0.5 & 26.9 & & & 0.6 & 40.4 & 0.2 & 7.3 & & & 0.4 & 38.0 & & \\
\hline LEAN & FW & 1.0 & 41.2 & 0.5 & 0.6 & 0.8 & 12.9 & 0.4 & 10.2 & & & 0.4 & 19.0 & 0.4 & 11.8 & & & 0.8 & 66.1 & & & & & 0.4 & 9.7 & & \\
\hline & SS & 1.0 & 24.6 & & & 0.3 & 11.7 & 1.0 & 30.2 & & & & & & & & & 0.8 & 54.1 & & & 0.2 & 20.5 & 0.5 & 12.0 & & \\
\hline SYFR & FW & & & & & 0.8 & 19.8 & & & & & & & 0.9 & 46.9 & & & & & & & & & & & 0.2 & 41.2 \\
\hline & SS & & & & & 1.0 & 58.3 & & & & & & & 0.6 & 13.0 & & & & & 0.3 & 16.5 & & & 0.4 & 22.6 & & \\
\hline PSLO & FW & & & & & & & & & & & 1.0 & 42.9 & 0.5 & 31.4 & & & 0.6 & 15.2 & & & & & & & 0.3 & 58.7 \\
\hline & SS & 0.7 & 30.7 & & & 0.2 & 6.7 & 0.2 & 15.8 & & & 0.5 & 16.1 & 0.4 & 23.5 & & & 0.7 & 57.0 & & & & & & & & \\
\hline TAMA & FW & 0.8 & 13.5 & & & 0.9 & 42.3 & & & & & 0.7 & 17.3 & & & & & & & 0.4 & 30.5 & 0.2 & 30.4 & 0.2 & 26.1 & & \\
\hline & SS & 0.8 & 18.7 & & & 1.0 & 33.0 & & & & & 0.9 & 16.7 & & & & & & & 0.4 & 16.0 & & & & & 0.3 & 39.6 \\
\hline PODU & FW & 1.0 & 33.6 & 0.4 & 16.7 & & & & & & & & & 0.2 & 10.7 & & & 0.9 & 49.4 & & & & & & & 0.3 & 28.6 \\
\hline & SS & 0.9 & 56.4 & 0.3 & 6.4 & & & & & & & & & & & & & 1.0 & 45.6 & & & & & & & 0.2 & 28.2 \\
\hline TURU & FW & 0.7 & 24.5 & 0.7 & 5.6 & & & & & & & & & & & & & & & 0.3 & 32.8 & & & 0.4 & 48.6 & & \\
\hline & SS & 0.8 & 23.5 & & & 0.4 & 30.4 & & & & & & & & & 0.3 & 9.0 & & & 0.8 & 48.5 & & & 0.2 & 10.7 & & \\
\hline TUAM & FW & & & & & & & & & & & 0.6 & 12.2 & & & 0.6 & 30.8 & 0.7 & 48.6 & 0.5 & 12.8 & & & 0.2 & 27.4 & & \\
\hline & SS & 0.4 & 19.3 & & & 1.0 & 41.7 & 0.3 & 9.9 & & & & & & & & & 0.5 & 25.8 & & & 0.3 & 32.5 & 0.3 & 11.8 & & \\
\hline SAAU & FW & 0.6 & 14.5 & & & 0.4 & 22.9 & & & & & & & & & 0.4 & 21.1 & 0.5 & 30.0 & & & 0.5 & 42.6 & & & & \\
\hline & SS & 1.0 & 46.0 & & & 0.8 & 30.1 & 0.3 & 7.8 & & & & & & & & & 0.3 & 24.7 & & & 0.7 & 53.9 & & & & \\
\hline PACO & FW & 0.2 & 17.4 & & & & & & & & & 0.8 & 24.5 & 0.5 & 23.4 & 0.2 & 26.2 & 0.6 & 65.4 & & & & & & & & \\
\hline & SS & & & & & & & & & & & 0.9 & 34.0 & & & & & 0.9 & 50.4 & & & & & & & 0.9 & 17.4 \\
\hline POME & FW & 1.0 & 26.5 & & & & & 0.9 & 56.8 & & & & & & & & & & & 0.4 & 34.8 & & & & & & \\
\hline & SS & & & & & & & & & 1.0 & 11.0 & 1.0 & 23.2 & 1.0 & 33.8 & & & 0.6 & 38.6 & & & & & & & & \\
\hline SUSU & FW & & & & & & & & & & & 0.4 & 10.6 & 1.0 & 58.4 & & & 0.7 & 62.2 & & & & & & & & \\
\hline & SS & & & & & & & & & 1.0 & 43.5 & 0.3 & 10.0 & 0.7 & 39.1 & & & 0.2 & 56.3 & & & & & & & & \\
\hline SESU & FW & & & 0.2 & 13.5 & 1.0 & 34.4 & 0.5 & 14.6 & & & & & & & & & & & 0.3 & 18.4 & 0.5 & 44.6 & 0.2 & 18.0 & & \\
\hline & SS & 0.9 & 40.0 & & & & & & & & & & & & & & & 0.8 & 36.3 & 0.8 & 25.6 & & & & & & \\
\hline SIFL & FW & 1.0 & 36.7 & 0.2 & 14.2 & 0.3 & 20.6 & & & & & & & & & & & 0.7 & 34.1 & & & & & & & & \\
\hline & SS & 1.0 & 68.2 & & & 0.5 & 5.2 & 0.4 & 14.6 & & & & & & & & & 0.7 & 42.9 & 0.2 & 15.9 & & & & & & \\
\hline MYMO & FW & & & & & 0.7 & 28.9 & 0.5 & 20.0 & & & & & & & & & & & 0.3 & 27.4 & & & 0.3 & 32.0 & & \\
\hline & SS & 0.2 & 11.5 & & & 0.4 & 28.3 & & & & & & & & & 0.3 & 32.1 & & & 0.3 & 27.4 & & & 0.3 & 32.0 & & \\
\hline $\begin{array}{l}{ }^{\dagger} \text { Codes of } \\
{ }^{\dagger} \mathrm{FW}=\mathrm{fa} \\
{ }^{\$} \text { Patch-sca } \\
\text { fractal din } \\
\text { Landscap } \\
\text { Contagion }\end{array}$ & $\begin{array}{l}\text { rd speci } \\
\text { vinter, S } \\
\text { variable } \\
\text { asion, D } \\
\text { cale var } \\
\text { and PR }\end{array}$ & $=$ spr & $\begin{array}{l}\text { Table } \\
\text { g-sum } \\
=\text { den } \\
\text { linear } \\
1=\mathrm{fr} \\
\text { pe ric }\end{array}$ & $\begin{array}{l}\text { mer. } \\
\text { sity o } \\
\text { distan } \\
\text { agme } \\
\text { hness. }\end{array}$ & $\begin{array}{l}\text { trees, } \\
\text { ce }(\mathrm{m}) \\
\text { atation }\end{array}$ & grad & $\begin{array}{l}=\text { den } \\
\text { rest se } \\
\text { ent pri }\end{array}$ & tleme & $\begin{array}{l}\text { shrul } \\
\text { nt. } \\
\text { comp }\end{array}$ & onent & $\mathrm{t}, \mathrm{PC} 2$ & $2=f r$ & $\begin{array}{l}\text { e heig } \\
\text { agme }\end{array}$ & tation & $\begin{array}{l}3 \mathrm{H}= \\
\text { cova }\end{array}$ & ate $\mathrm{p}$ & incip & com & $\begin{array}{l}\text { ight, } \\
\text { onen }\end{array}$ & $\mathrm{IJI}=$ & $\begin{array}{l}\text { otch } \\
\text { inter }\end{array}$ & pers & . & jux & ositi & $\mathrm{CO}$ & \\
\hline
\end{tabular}

taking advantage of holes made by medium-sized woodpeckers. The existing Espinal forest is mostly secondary, where stands commonly include trees of different sizes and ages. In summary, the forest patch characteristics and historical land use, e.g., proportion of shrub cover, degradation, livestock ranching, and extraction of mature trees, may explain the lack of an observed inverse relationship between tree density and availability of nest cavities. Regarding other species like Monk Parakeet and Picui Ground Dove, preference for patches characterized by reduced tree density could facilitate the detection of potential nest predators (Peris and Aramburú 1995, Eberhard 1998).

Most species in our study did not respond to forest patch size contrary to other studies that reported a response (positive or negative) between bird abundance and patch size (Robinson et al. 1995, Estades 2001, Lindenmayer et al. 2002, Ferraz et al. 2007). This suggests ecological processes manifested at certain spatial scales may be of greater importance. For example, patch size response may be influenced by species-specific characteristics such as life history strategies or attributes of the landscape. Similarly, abundant species may be present in small patches (MacNally et al. 2000), other species may increase in abundance in proportion with patch size (Vickery et al. 1994, Johnson and Igl 2001), while others may exhibit no definite pattern (Andrén 1994, Estades and Temple 1999). In our study, the relatively weak influence of patch size could be related to the absence of clear statistical differences between landscapes. However, this relationship was identified, i.e., PC1, at the landscape scale, suggesting large tracts of continuous forest in mosaic 1 could still support vulnerable bird species or those sensitive to fragmentation. Conversely, these species were not abundant in landscapes characterized by relatively small forest patches surrounded by widespread agricultural development. These patterns suggest ecological thresholds, i.e., response, may exist for species requiring particular forest habitat conditions (Luck 2005, Betts et al. 2010), such as the Narrow-billed Woodcreeper, Scimitar-billed Woodcreeper, or Brown Cacholote.

Patch shape complexity was consistently important, a result similar to other published reports regarding its relationship to bird 
abundance (Hawrot and Niemi 1996, Magrach et al. 2011). Simpler patch shapes in our study area favored cavity nesting birds like Woodcreepers and species like Red-crested Cardinal and Suiriri Flycatcher. Patch shape is determined by the interaction between area and perimeter, which in turn determines the amount of core habitat in a fragmented landscape (Laurance and Yensen 1991, Collinge 1996). We did not quantify core area, given the extensive information in the published literature regarding core area differences among species (Watson et al. 2004, Zurita et al. 2012). Further, edge effect relationships to bird species were not part of our study objectives. Additionally, edge was not clearly defined in the Espinal forest compared to other forested biomes of southern South America, such as the Chaco forests of Argentina (Lopez de Casenave et al. 1998, Sosa 2008, Banks-Leite et al. 2010, Zurita et al. 2012). The absence of a clear edge in Espinal forest may be related to the semixerophytic nature of these forests, dominated by plant species adapted to harsh environmental conditions typical of edges, and the influence of cattle grazing in Entre Ríos province (Cano et al. 1980, Sabattini et al. 2002).

Previous information on bird use of forest edge versus interior differed among published studies. Sosa (2008) identified Masked Gnatcatcher as a forest interior species, yet in our study this was more abundant in landscapes characterized by small forest patches with little to no core habitat. Conversely, Golden-billed Saltator was reported as exclusively associated with forest edge (Sosa 2008). However, it was less abundant in study landscapes characterized by small patches and therefore lesser forest interior area. Furthermore, Dardanelli et al. (2006) differentiated use of forest interior and edge by some of the same species in our study and reported contrasting patterns to results by Sosa (2008). These differences may be due to the fact that while these other studies were also conducted in the Espinal region, the composition of tree species differed from our study area. Weather conditions in our study region also differed from Sosa (2008). Further, forest management practices in relation to fire and extractions during the first half of the 20th century resulted in changes to vegetation structure (Dussart et al. 2011). Most importantly, spatial scale may explain the differences among our study and Sosa (2008), given the area of this previous study was 9344 ha, equivalent to just one of 18 landscapes (10,000 ha) in our study.

Landscape scale factors related to amount and spatial configuration of forest were more important than other cover types, indicating bird species in our sample responded to patterns associated to forest habitat loss and fragmentation. Although many published studies highlight the quality of the matrix when determining composition and abundance of species within patches (Laurance 1991, Gascon et al. 1999, Kotze and Samways 1999, Cook et al. 2002), our results suggested the surrounding matrix exhibited a limited influence on bird abundance. A possible explanation could be that many of the selected bird species use forest patches both for feeding and nesting, which could limit their use of the matrix. On the other hand, the movements and resource selection patterns of species using both forest patches and surrounding matrix are unknown for the Espinal, so changes in land use, i.e. soybeans one year, followed by corn, may not influence avian distribution patterns. Also, bird species that actively forage in the matrix, e.g., Picui Ground Dove, may have access to food equally provided by different land use types, resulting in weak responses to quantity and spatial arrangement of crops that characterized the matrix in our study. Finally, there may be additional variables that were not incorporated or the manner in which some of the incorporated variables were measured may have failed to capture any potential influences on the bird community.

Some species in our study, e.g., Scimitar-billed Woodcreeper, Narrow-billed Woodcreeper, Brown Cacholote, Creamy-bellied Thrush, and Red-crested Cardinal, were more abundant in landscapes dominated by closely arranged, interconnected forest patches. This may reflect the benefit of increased landscape connectivity and access to available patch resources (Andrade and Marini 2001, Lees and Peres 2008). On the other hand, Picui Ground Dove, Grayish Baywing, Great Antshrike, and Saffron Finch were more abundant in landscapes characterized by greater forest fragmentation. These species are known generalists commonly found in modified agricultural landscapes. Their preference for landscapes characterized by isolated forest patches likely reflects their greater ecological plasticity in resource use (Fraser and Stutchbury 2004, Thornton et al. 2011). Our twoscale approach to assess bird responses to environmental characteristics highlighted the differential use of landscape elements by a representative sample of birds in the Espinal region. Hence, negative impacts of loss and fragmentation of native forest may not necessarily be offset by local measures alone, such as retaining large trees. Landscape scale measures describing structure, amount, and spatial configuration of forest should be considered to ensure the regional persistence of bird species. This information contributes reliable knowledge to integrate in the design of conservation measures for agricultural landscapes in the Espinal region of Argentina.

\section{CONCLUSIONS}

In the absence of land use regulations agricultural expansion will continue in the province of Entre Ríos, with increasing alteration of native forest cover, spatial configuration, and structure within patches. Our results provide useful and reliable information for the development of management and land conservation plans. As such, these may serve to provide guidance on landscape conservation design for the fragmented agroecosystems of the region. At the patch scale, retaining larger trees in forest patches will help maintain the abundance of forest species while allowing agricultural activities inside regular lots. At the landscape scale, limiting the conversion of forests to agricultural lands, avoiding further fragmentation of forest patches, and designating areas where large forest fragments are protected and maintained will benefit forest specialist species. To prevent major negative effects on biodiversity, additional conservation efforts are necessary. Some of these are currently in progress, including the National Law to protect Argentine forests. However, its effectiveness will depend on decision makers and land owners given the lack of control on land use policies. If soybean production and cattle ranching continue to expand across the Espinal forest ecosystem without land use planning, the negative effects of these activities on avian biodiversity will likely continue to increase.

Responses to this article can be read online at: http://www.ace-eco.org/issues/responses.php/1222 


\section{Acknowledgments:}

Funding for this work was provided by the National Agricultural Technology Institute (INTA), through the Projects AERN 2624, 2622, and PNNAT 1128052 of Argentina. We thank the numerous farmers that kindly granted access to their properties. We also want to thank the valuable fieldwork assistance provided by J. Mancini, L. Antoniazzi, R. Lorenzón, P. Cavallero, L. Leiva, N. Bossel, B. Jauberts, and $G$. Bonomi as well as the advice in processing satellite images provided by $S$. Havrylenko and T. Kuemmerle. Thanks to $S$. Canavelli and G. Gavier for their collaboration on methodological aspects and helpful comments and thanks to A. Cerezo and $S$. Benitez-Vieyra for assistance in preliminary statistical analysis. Thanks to K. Evans and one anonymous reviewer for valuable comments and suggestions on an earlier version of the manuscript. The use of trade, firm, or product names is for descriptive purposes only and does not constitute endorsement by the U.S. Government.

\section{LITERATURE CITED}

Aizen, M. A., L. A. Garibaldi, and M. Dondo. 2009. Expansión de la soja y diversidad de la agricultura Argentina. Ecología Austral 19:45-54.

Andrade, R. D., and M. A Marini. 2001. Movement of birds in natural forest patches in southeast Brazil. Pages 125-136 in J. L. B. Albuquerque, J. F. Cândido Jr., F. C. Straube, and A. L. Ross, editors. Ornitologia e Conservacão: da Ciência às Estratégias. Editora UNISUL, Tubarão, Brazil.

Andrén, H. 1994. Effects of habitat fragmentation on birds and mammals in landscapes with different proportions of suitable habitat: a review. Oikos 71:355-366. http://dx.doi.org/10.2307/3545823

Antongiovanni, M., and J. P. Metzger. 2005. Influence of matrix habitats on the occurrence of insectivorous bird species in Amazonian forest fragments. Biological Conservation 122:441-451. http://dx.doi.org/10.1016/j.biocon.2004.09.005

Baillie, J., C. Hilton-Taylor, and S. N. Stuart. 2004. IUCN red list of threatened species. A global species assessment. IUCN Gland, Switzerland.

Banks-Leite, C., R. M. Ewers, and J. P. Metzger. 2010. Edge effects as the principal cause of area effects on birds in fragmented secondary forest. Oikos 119:918-926. http://dx.doi.org/10.1111/ j.1600-0706.2009.18061.x

Bennett, A. F. 2003. Linkages in the landscape: the role of corridors and connectivity in wildife conservation. Second edition. IUCN, Gland, Switzerland. http://dx.doi.org/10.2305/IUCN.CH.2004. FR.1.en

Berg, Å, B. Ehnström, L. Gustafsson, T. Hallingbäck, M. Jonsell, and J. Weslien. 1994. Threatened plant, animal, and fungus species in Swedish forests: distribution and habitat associations. Conservation Biology 8:718-731. http://dx.doi.org/10.1046/ j.1523-1739.1994.08030718.x

Betts, M. G., J. C. Hagar, J. W. Rivers, J. D. Alexander, K. McGarigal, and B. C. McComb. 2010. Thresholds in forest bird occurrence as a function of the amount of early-seral broadleaf forest at landscape scales. Ecological Applications 20 (8):2116-2130. http://dx.doi.org/10.1890/09-1305.1

Bibby, C. J., N. D. Burgess, D. A. Hill, and S.H. Mustoe. 2000. Bird census techniques. Second edition. Academic Press, London, UK.

Boulinier, T., J. D. Nichols, J. E. Hines, J. R. Sauer, C. H. Flather, and K. H. Pollock. 2001. Forest fragmentation and bird community dynamics: inference at regional levels. Ecology 82:1159-1169. http://dx.doi.org/10.1890/0012-9658(2001)082[1159: FFABCD]2.0.CO;2

Brawn, J. D. 1988. Selectivity and ecological consequences of cavity nesters using natural vs. artificial nest sites. Auk 105:789-791.

Buckland, S. T., D. R. Anderson, K. P. Burham, J. L. Laake, D. L. Borchers, and L. Thomas. 2001. Introduction to distance sampling. Estimating abundance of biological populations. Oxford University Press, Oxford, UK.

Burnham, K. P., and D. R Anderson. 2002. Model selection and multimodel inference: a practical information-theoretical approach. Second edition. Springer-Verlag, New York, New York, USA. http://dx.doi.org/10.1007/b97636

Cabrera, A. L. 1994. Regiones fitogeográficas Argentinas. Pages 1-85 in W. F. Kugler, editor. Enciclopedia argentina de agricultura y jardinería. Tomo II, fascículo 1. Ed. ACME, Buenos Aires, Argentina.

Cano, E., G. Casagrande, H. A. Conti, B. Fernández, R. Hevia, J. C. Lea Plaza, D. Maldonado Pinedo, H. Martínez, M. A. Montes, and C. A. Peña Zubiate. 1980. Inventario integrado de los recursos naturales de la provincia de La Pampa. INTA-UNLPamGobierno de La Pampa, Santa Rosa, Argentina.

Canterbury, G. E., T. E. Martin, D. R. Petit, L. J. Petit, and D. F. Bradford. 2000. Bird communities and habitat as ecological indicators of forest condition in regional monitoring. Conservation Biology 14(2):544-558. http://dx.doi.org/10.1046/ j.1523-1739.2000.98235.X

Cockle, K. L., K. Martin, and G. Robledo. 2012. Linking fungi, trees, and hole-using birds in a Neotropical tree-cavity network: pathways of cavity production and implications for conservation. Forest Ecology and Management 264:210-219. http://dx.doi. org/10.1016/j.foreco.2011.10.015

Collinge, S. K. 1996. Ecological consequences of habitat fragmentation: implications for landscape architecture and planning. Landscape Urban Plan 36:59-77. http://dx.doi. org/10.1016/S0169-2046(96)00341-6

Congalton, R. G., and K. Green. 2009. Assessing the accuracy of remotely sensed data: principles and practices. Second edition. CRC Press, Boca Raton, Florida, USA. http://dx.doi. org/10.1201/9781420048568

Cook, W. M., K. T. Lane, B. L. Foster, and R. D. Holt. 2002. Island theory, matrix effects and species richness patterns in habitat fragments. Ecology Letters 5:619-623. http://dx.doi. org/10.1046/j.1461-0248.2002.00366.x 
Cottam, G., and J. T. Curtis. 1956. The use of distance measures in phytosociological sampling. Ecology 37:451-460. http://dx.doi. org/10.2307/1930167

Cunningham, M. A., and D. H. Johnson. 2006. Proximate and landscape factors influence grassland bird distributions. Ecological Applications 16:1062-1075. http://dx.doi.org/10.1890/1051-0761 (2006)016[1062:PALFIG]2.0.CO;2

Dardanelli, S., M. L. Nores, and M. Nores. 2006. Minimum area requirements of breeding birds in fragmented woodland of Central Argentina. Diversity and Distributions 12(6):687-693. http://dx.doi.org/10.1111/j.1472-4642.2006.00266.x

De la Fuente, E. B., and S. A. Suárez. 2008. Problemas ambientales asociados a la actividad humana: la agricultura. Ecología Austral 18:239-252.

De la Peña, M. R., and M. Rumboll. 1998. Birds of southern South America and Antarctica. Princeton University Press, Princeton, New Jersey, USA.

Di Rienzo, J. A., F. Casanoves, M. G. Balzarini, L. Gonzalez, M. Tablada, and C. W. Robledo. 2010. InfoStat versión 2010. Grupo InfoStat, Universidad Nacional de Córdoba, Facultad de Ciencias Agropecuarias, Córdoba, Argentina.

dos Anjos, L. 2006. Bird species sensitivity in a fragmented landscape of the Atlantic Forest in Southern Brazil. Biotropica 38:229-234. http://dx.doi.org/10.1111/j.1744-7429.2006.00122.x

Dussart, E. G., C. C. Chirino, E. A. Morici, and R. H. Peinetti. 2011. Reconstrucción del paisaje del caldenal pampeano en los últimos 250 años. Quebracho 19(1,2):54-65.

Eberhard, J. R. 1998. Breeding biology of the Monk parakeet. Wilson Bulletin 110:463-473.

Engler, P. L., and G. R. Vicente. 2009. Caracterización y localización de las formas de organización social predominantes de las unidades agropecuarias de Entre Ríos. X Congreso Argentino de Ingeniería Rural y II del MERCOSUR. Rosario, Argentina

Estades, C. F. 2001. The effect of breeding-habitat patch size on bird population density. Landscape Ecology 16:161-173. http:// dx.doi.org/10.1023/A:1011197432467

Estades, C. F., and S. A. Temple. 1999. Deciduous-forest bird communities in a fragmented landscape dominated by exotic pine plantations. Ecological Applications 9:573-585. http://dx.doi. org/10.1890/1051-0761(1999)009[0573:DFBCIA]2.0.CO;2

Fahrig, L. 2003. Effects of habitat fragmentation on biodiversity. Annual Review of Ecology, Evolution, and Systematics 34 (1):487-515. http://dx.doi.org/10.1146/annurev.ecolsys.34.011802.132419

Ferraz, G., J. D. Nichols, J. E. Hines, P. C. Stouffer, R. O. Bierregaard, and T. E. Lovejoy. 2007. A large-scale deforestation experiment: effects of patch area and isolation on Amazon birds. Science 315(5809):238-241. http://dx.doi.org/10.1126/science.1133097

Flack, J. A. D. 1976. Bird populations of aspen forests in western North America. Ornithological Monographs 19:1-97. http://dx. doi.org/10.2307/40166754

Fletcher, Jr., R. J., and R. R. Koford. 2002. Habitat and landscape associations of breeding birds in native and restored grasslands.
Journal of Wildlife Management 66:1011-1022. http://dx.doi. org/10.2307/3802933

Food and Agriculture Organization of the United Nations (FAO). 2016. Global forest resources assessment 2015. How are the world's forests changing? FAO, Rome, Italy. [online] URL: http://www. fao.org/resources/infographics/infographics-details/en/c/325836/

Foody, G. M., and A. Mathur. 2004. A relative evaluation of multiclass image classification by support vector machines. IEEE Transactions on Geoscience and Remote Sensing 42:1335-1343. http://dx.doi.org/10.1109/TGRS.2004.827257

Forman, R. T. T. 1995. Land mosaics. The ecology of landscapes and regions. Cambridge University Press, Cambridge, UK.

Forman, R. T. T. 2006. Good and bad places for roads: effects of varying road and natural pattern on habitat loss, degradation, and fragmentation. Pages 164-174 in C. L. Irwin, P. Garrett, K. P. McDermott, editors. Proceedings of the 2005 International Conference on Ecology and Transportation. Center for Transportation and the Environment, North Carolina State University, Raleigh, North Carolina, USA.

Fraser, G. S., and B. J. M. Stutchbury. 2004. Area-sensitive forest birds move extensively among forest patches. Biological Conservation 118:377-387. http://dx.doi.org/10.1016/j.biocon.2003.06.006

Fraterrigo, J. M., S. M. Pearson, and M. G. Turner. 2009. Joint effects of habitat configuration and temporal stochasticity on population dynamics. Landscape Ecology 24:863-877. http://dx. doi.org/10.1007/s10980-009-9364-6

García Del Rey, E., and W. Cresswell. 2005. Density estimates, microhabitat selection and foraging behaviour of the endemic Blue Chaffinch Fringilla teydea on Tenerife (Canary Islands). Ardeola 52(2):305-317.

Gascon, C., T. E. Lovejoy, R. O. Bierregaard, J. R. Malcolm, P. C. Stouffer, H. L. Vasconcelos, W. F. Laurance, B. Zimmerman, M. Tocher, and S. Borges. 1999. Matrix habitat and species richness in tropical forest remnants. Biological Conservation 91 (2):223-229. http://dx.doi.org/10.1016/S0006-3207(99)00080-4

Gasparri, N. I., and H. R. Grau. 2009. Deforestation and fragmentation of Chaco dry forest in NW Argentina (1972-2007). Forest ecology and Management 258(6):913-921. http://dx.doi. org/10.1016/j.foreco.2009.02.024

Gavier-Pizarro, G. I., N. C. Calamari, J. J. Thompson, S. B. Canavelli, L. M. Solari, J. Decarre, A. P. Goijman, R. P. Suarez, J. N. Bernardos, and M. E. Zaccagnini. 2012. Expansion and intensification of row crop agriculture in the Pampas and Espinal of Argentina can reduce ecosystem service provision by changing avian density. Agriculture, Ecosystems \& Environment 154:44-55. http://dx.doi.org/10.1016/j.agee.2011.08.013

Gehring, T. M., and R. K. Swihart. 2003. Body size, niche breadth, and ecologically scaled responses to habitat fragmentation: mammalian predators in an agricultural landscape. Biological Conservation 109:283-295. http://dx.doi.org/10.1016/S0006-3207 (02)00156-8

Geist, H. J., and E. F. Lambin. 2002. Proximate causes and underlying driving forces of tropical deforestation. Bioscience 52:143-150. http://dx.doi.org/10.1641/0006-3568(2002)052[0143: PCAUDF]2.0.CO;2 
Graham, C. H., and J. G. Blake. 2001. Influence of patch and landscape-level factors on bird assemblages in a fragmented tropical landscape. Ecological Applications 11(6):1709-1721. http://dx.doi.org/10.1890/1051-0761(2001)011[1709:IOPALL]2.0. $\mathrm{CO} ; 2$

Guisan, A., T. C. J. Edwards, and T. Hastie. 2002. Generalized linear and generalized additive models in studies of species distributions: setting the scene. Ecological Modelling 157:89-100. http://dx.doi.org/10.1016/S0304-3800(02)00204-1

Hanski, I. 2011. Habitat loss, the dynamics of biodiversity, and a perspective on conservation. AMBIO 40(3):248-255. http://dx. doi.org/10.1007/s13280-011-0147-3

Hawrot, R. Y., and G. J. Niemi. 1996. Effects of edge type and patch shape on avian communities in a mixed conifer-hardwood forest. Auk 113:586-598. http://dx.doi.org/10.2307/4088979

Henle, K., K. F. Davies, M. Kleyer, C. Margules, and J. Settele. 2004. Predictors of species sensitivity to fragmentation. Biodiversity \& Conservation 13:207-251. http://dx.doi.org/10.1023/ B:BIOC.0000004319.91643.9e

Hoekstra, J. M., T. M. Boucher, T. H. Ricketts, and C. Roberts. 2005. Confronting a biome crisis: global disparities of habitat loss and protection. Ecology Letters 8(1):23-29. http://dx.doi. org/10.1111/j.1461-0248.2004.00686.X

Holland, G. J., and A. F. Bennett. 2009. Differing responses to land-scape change: implications for small mammal assemblages in forest fragments. Biodiversity and Conservation 18:2997-3016. http://dx.doi.org/10.1007/s10531-009-9621-7

Horn, D. J., and R. R. Koford. 2006. Could the area-sensitivity of some grassland birds be affected by landscape composition? Pages 109-116 in D. Egan, and J. A. Harrington, editors. Proceedings of the 19th North American prairie conference. University of Wisconsin, Madison, Wisconsin, USA.

Huang, C., L. S. Davis, and J. R. S. Townshend. 2002. An assessment of support vector machines for land cover classification. International Journal of Remote Sensing 23:725-749. http://dx.doi.org/10.1080/01431160110040323

Isaaks, E. H., and R. M. Srivastava. 1989. An introduction to applied geostatistics. Oxford University Press, New York, New York, USA.

Janz, A., S. van der Linden, B. Waske, and P. Hostert. 2007. imageSVM, a user-oriented tool for advanced classification of hyperspectral data using support vector machines. Proceedings of the 5th EARSeL SIG Imaging Spectroscopy, Bruges, Belgium.

Johnson, D. H., and L. D. Igl. 2001. Area requirements of grassland birds: a regional perspective. Auk 118:24-34. http://dx. doi.org/10.1642/0004-8038(2001)118[0024:AROGBA]2.0.CO;2

Johnston, J. C., and R. L. Holberton. 2009. Forest management and temporal effects on food abundance for a ground-foraging bird (Catharus guttatus). Forest Ecology and Management 258:1516-1527. http://dx.doi.org/10.1016/j.foreco.2009.07.012

Kotze, D. J., and M. J. Samways. 1999. Invertebrate conservation at the interface between the grassland matrix and natural Afromontane forest fragments. Biodiversity \& Conservation 8:1339-1363. http://dx.doi.org/10.1023/A:1008945302029
Kuemmerle, T., P. Hostert, V. C. Radeloff, S. van der Linden, K. Perzanowski, and I. Kruhlov. 2008. Cross-border comparison of post-socialist farmland abandonment in the Carpathians. Ecosystems 11(4):614. http://dx.doi.org/10.1007/s10021-008-9146$\mathrm{Z}$

Laurance, W. F. 1991. Ecological correlates of extinction proneness in Australian tropical rain forest mammals. Conservation Biology 5:79-89. http://dx.doi.org/10.1111/j.1523-1739.1991. tb00390.x

Laurance, W. F., and E. Yensen. 1991. Predicting the impacts of edge effects in fragmented habitats. Biological Conservation 55:77-92. http://dx.doi.org/10.1016/0006-3207(91)90006-U

Lees, A. C., and C. A. Peres. 2008. Conservation value of remnant riparian forest corridors of varying quality for Amazonian birds and mammals. Conservation Biology 22:439-449. http://dx.doi. org/10.1111/j.1523-1739.2007.00870.x

Lens, L., S. Van Dongen, K. Norris, K., M. Githiru, and E. Matthysen. 2002. Avian persistence in fragmented rainforest. Science 298(5596):1236-1238. http://dx.doi.org/10.1126/science.1075664

Lewis, J. P., S. Noetinger, D. E. Prado, and I. Barberis. 2009. Woody vegetation structure and composition of the last relicts of Espinal vegetation in subtropical Argentina. Biodiversity and Conservation 18:3615-3628. http://dx.doi.org/10.1007/s10531-009-9665-8

Lindenmayer, D. B., R. B. Cunningham, C. F. Donnelly, H. Nix, and B. D. Lindenmayer. 2002. Effects of forest fragmentation on bird assemblages in a novel landscape context. Ecological Monographs 72:1-18. http://dx.doi.org/10.1890/0012-9615(2002) 072[0001:EOFFOB]2.0.CO;2

Lopez de Casenave, J., J. P. Pelotto, S. M. Caziani, M. Mermoz, and J. Protomastro. 1998. Responses of avian assemblages to a natural edge in a Chaco semiarid forest in Argentina. Auk 115:425-435. http://dx.doi.org/10.2307/4089201

Luck, G. W. 2005. An introduction to ecological thresholds. Biological Conservation 124:299-300. http://dx.doi.org/10.1016/j. biocon.2005.01.042

Lundberg, J., and F. Moberg. 2003. Mobile link organisms and ecosystem functioning: implications for ecosystem resilience and management. Ecosystems 6:87-98. http://dx.doi.org/10.1007/ s10021-002-0150-4

MacNally, R. 2002. Multiple regression and inference in ecology and conservation biology: further comments on identifying important predictor variables. Biodiversity and Conservation 11:1397-1401. http://dx.doi.org/10.1023/A:1016250716679

MacNally, R., A. F. Bennett, and G. Horrocks. 2000. Forecasting the impacts of habitat fragmentation. Evaluation of speciesspecific predictions of the impact of habitat fragmentation on birds in the box-ironbark forests of central Victoria, Australia. Biological Conservation 95:7-29. http://dx.doi.org/10.1016/ S0006-3207(00)00017-3

Magrach, A., A. R. Larrinaga, and L. Santamaría. 2011. Changes in patch features may exacerbate or compensate for the effect of habitat loss on forest bird populations. PLoS ONE 6(6):e21596. http://dx.doi.org/10.1371/journal.pone.0021596 
Manning, A. D., D. B. Lindenmayer, and S. C. Barry. 2004. The conservation implications of bird reproduction in the agricultural "matrix": a case study of the vulnerable superb parrot of southeastern Australia. Biological Conservation 120:363-374. http://dx. doi.org/10.1016/j.biocon.2004.03.008

Martin, T. E. 1998. Are microhabitat preferences of coexisting species under selection and adaptive? Ecology 79:656-670. http:// dx.doi.org/10.1890/0012-9658(1998)079[0656:AMPOCS]2.0.CO;2

Matteucci, S. 2012. Ecorregión Espinal. Pages 349-390 in J. Morello, S. Matteucci, A. F. Rodriguez, and M. E. Silva, editors. Ecorregiones y Complejos Ecosistémicos Argentinos. Orientación Gráfica Editora SRL, Buenos Aires, Argentina.

Mazerolle, M. J., and M.-A. Villard. 1999. Patch characteristics and landscape context as predictors of species presence and abundance: a review. Ecoscience 6:117-124. http://dx.doi. org/10.1080/11956860.1999.11952204

McComb, W. C. 1999. Forest fragmentation: wildlife and management implications synthesis of the conference. Pages 295-301 in J. A. Rochelle, L. A. Lehmann, and J. Wisniewski, editors. Forest fragmentation: wildlife and management implications. Brill, New York, USA.

McCune, B., J. B. Grace, and D. L. Urban. 2002. Analysis of ecological communities. MjM Software Design, Gleneden Beach, Oregon, USA.

McGarigal, K., S. A. Cushman, and E. Ene. 2012. FRAGSTATS v4: Spatial pattern analysis program for categorical and continuous maps. University of Massachusetts, Amherst, Massachusetts, USA. [online] URL: http://www.umass.edu/landeco/research/ fragstats/fragstats.html

Menéndez, J. L., and S. M. La Roca. 2007. Primer inventario nacional de bosques nativos. Inventario de Campo de la región del Espinal distritos Caldén y Nandubay. Informe Regional Espinal segunda etapa. Secretaría de Ambiente y Desarrollo Sustentable de la Nación, Buenos Aires, Argentina.

Merriam, G., and J. Wegner. 1992. Local extinctions, habitat fragmentation, and ecotones. Pages 150-169 in A. J. Hansen and F. Di Castri, editors. Landscape boundaries: consequences for biotic diversity and ecological flows. Springer Verlag, New York, New York, USA. http://dx.doi.org/10.1007/978-1-4612-2804-2_7

Munguía-Rosas, M. A., and S. Montiel. 2014. Patch size and isolation predict plant species density in a naturally fragmented forest. PLoS One 9(10):e111742. http://dx.doi.org/10.1371/ journal.pone.0111742

Muñoz, J. D. D., S. Milera, C. Romero, and A. Brizuela. 2005. Bosques nativos y selvas ribereñas en la provincia de Entre Ríos. INSUGEO. Misceláneas 14:169-182.

Nadkarni, N. M., and T. J. Longino. 1990. Invertebrates in the canopy and ground organic matter in a Neotropical montane forest, Costa Rica. Biotropica 22:286-289. http://dx.doi. org/10.2307/2388539

Narosky, T., and D. Yzurieta. 2010. Aves de Argentina y Uruguay: Guía de identificación. 16 ${ }^{\mathrm{a}}$ edition. Vázquez Mazzini Editores Buenos Aires, Argentina.
O’Connell T. J., L. E. Jackson, and R. P. Brooks. 2000. Bird guilds as indicators of ecological condition in the central Appalachians. Ecological Applications 10(6):1706-1721. http://dx.doi. org/10.1890/1051-0761(2000)010[1706:BGAIOE]2.0.CO;2

Pal, M., and P. M. Mather. 2005. Support vector machines for classification in remote sensing. International Journal of Remote Sensing 26:1007-1011. http://dx.doi.org/10.1080/01431160512331314083

Peris, S. J., and R. Aramburú. 1995. Reproductive phenology and breeding success of the Monk Parakeet (Myiopsitta monachus monachus) in Argentina. Studies on Neotropical Fauna and Environment 30(2):115-119. http://dx.doi.org/10.1080/01650529509360948

Prugh, L. R., K. E. Hodges, A. R. E Sinclair, and J. S. Brashares. 2008. Effect of habitat area and isolation on fragmented animal populations. Proceedings of the National Academy of Sciences 105:20770-20775 http://dx.doi.org/10.1073/pnas.0806080105

R Development Core Team. 2013. R: A language and environment for statistical computing. R Foundation for Statistical Computing, Vienna, Austria. [online] URL: https://cran.r-project.org/

Rempel, R. S., D. Kaukinen, and A. P. Carr. 2012. Patch analyst and patch grid. Ontario Ministry of Natural Resources, Centre for Northern Forest Ecosystem Research, Thunder Bay, Ontario, Canada.

Renfrew, R. B., and C. A. Ribic. 2008. Multiscale models of grassland passerine abundance in a fragmented system in Wisconsin. Landscape Ecology 23:181-193. http://dx.doi. org/10.1007/s10980-007-9179-2

Ribic, C. A., and D. A. Sample. 2001. Associations of grassland birds with landscape factors in southern Wisconsin. American Midland Naturalist 146(1):105-121. http://dx.doi.org/10.1674/0003-0031 (2001)146[0105:AOGBWL]2.0.CO;2

Robinson, S. K., F. R. Thompson III, T. M. Donovan, D. R. Whitehead, and J. Faaborg. 1995. Regional forest fragmentation and the nesting success of migratory birds. Science 267:1987-1990. http://dx.doi.org/10.1126/science.267.5206.1987

Romhan de la Vega, C. F., H. Ramírez, and J. L. Treviño. 1994. Dendrometría. Universidad Autónoma de Chapingo, Texcoco, México.

Sabattini, R. A., N. Muzzachiodi, and A. F. Dorsch. 2002. Manual de Prácticas de Manejo del Monte Nativo. UNER, Entre Ríos, Argentina.

Savard, J. L., and T. D. Hooper. 1995. Influence of survey length and radius size on grassland bird surveys by point counts at Williams Lake, British Columbia. Pages 49-62 in C. J. Ralph, J. R. Sauer, and S. Droege, editors. Monitoring bird populations by point counts. General Technical Report PSW-GTR-149. U.S. Forest Service, Pacific Southwest Research Station, Albany, California, USA.

Schrag, A. M., M. E. Zaccagnini, N. Calamari, and S. Canavelli. 2009. Climate and land-use influences on avifauna in central Argentina: broad-scale patterns and implications of agricultural conversion for biodiversity. Agriculture, Ecosystems and Environment 132:135-142. http://dx.doi.org/10.1016/j.agee.2009.03.009 
Seavy, N. E., S. Quader, J. D. Alexander, and C. J. Ralph. 2005. Generalized linear models and point count data: statistical considerations for the design and analysis of monitoring studies. Pages 744-753 in C. J. Ralph and T. D. Rich, editors. Bird conservation implementation and integration in the Americas. General Technical Report PSW-GTR-191. U.S. Forest Service, Pacific Southwest Research Station, Albany, California, USA.

Şekercioglu, C. H., P. R. Ehrlich, G. C. Daily, D. Aygen, D. Goehring, and R. F. Sandí. 2002. Disappearance of insectivorous birds from tropical forest fragments. Proceedings of the National Academy of Sciences 99(1):263-267. http://dx.doi.org/10.1073/ pnas.012616199

Şekercioglu, C. H., and N. S. Sodhi. 2007. Conservation biology: predicting birds' responses to forest fragmentation. Current Biology 17(19):838-840. http://dx.doi.org/10.1016/j.cub.2007.07.037

Skórka, P., M. Lenda, and W. J. Sutherland. 2016. Response of young and adult birds to the same environmental variables and different spatial scales during post breeding period. Landscape Ecology 31:2063-2078. http://dx.doi.org/10.1007/s10980-016-0382$\mathrm{x}$

Sosa, R. A. 2008. Efectos de la fragmentación del bosque de caldén sobre las comunidades de aves en el centro-este de La Pampa. Tesis Doctoral. Universidad de Buenos Aires, Argentina.

Suarez-Rubio, M., and J. R. Thomlinson. 2009. Landscape and patch-level factors influence bird communities in an urbanized tropical island. Biological Conservation 142:1311-1321. http://dx. doi.org/10.1016/j.biocon.2008.12.035

Thornton, D. H., L. C. Branch, and M. E. Sunquist. 2011. The influence of landscape, patch, and within patch factors on species presence and abundance: a review of focal patch studies. Landscape Ecology 26:7-18. http://dx.doi.org/10.1007/s10980-010-9549$\mathrm{z}$

Uezu, A., J. P. Metzger, and J. M. E. Vielliard. 2005. Effects of structural and functional connectivity and patch size on the abundance of seven Atlantic Forest bird species. Biological Conservation 123:507-519. http://dx.doi.org/10.1016/j.biocon.2005.01.001

van der Linden, S., A. Rabe, and A. Okujeni. 2009. imageSVM classification, application manual: imageSVM version 2.0. Humboldt-Universität zu Berlin, Germany.

Vickery, P. D., M. L. Hunter, and S. M. Melvin. 1994. Effects of habitat area on the distribution of grassland birds in Maine. Conservation Biology 8:1087-1097. http://dx.doi.org/10.1046/ j.1523-1739.1994.08041087.x

Wang, F., G. Blanchet, and N. Koper. 2014. Measuring habitat fragmentation: an evaluation of landscape pattern metrics. Methods in Ecology and Evolution 5(7):634-646. http://dx.doi. org/10.1111/2041-210X.12198
Watson, J. E. M., R. J. Whittaker, and T. P. Dawson. 2004. Habitat structure and proximity to forest edge affect the abundance and distribution of forest-dependent birds in tropical coastal forests of southeastern Madagascar. Biological Conservation 120:311-327. http://dx.doi.org/10.1016/j.biocon.2004.03.004

Wilson, M. G. 2008. Uso de la tierra en el área de bosque nativo de Entre Ríos, Argentina. Tesis Doctoral. Universidad de la Coruña, España.

Ye, X., T. Wang, and A. K. Skidmore. 2013. Spatial pattern of habitat quality modulates population persistence in fragmented landscapes. Ecological Research 28(6):949-958. http://dx.doi. org/10.1007/s11284-013-1077-2

Zanette, L., and B. Jenkins. 2000. Nesting success and nest predators in forest fragments: a study using real and artificial nest. Auk 117:445-454. http://dx.doi.org/10.1642/0004-8038(2000)117 [0445:NSANPI]2.0.CO;2

Zurita, G. A., and M. I. Bellocq. 2007. Pérdida y fragmentación de la Selva Paranaense: efectos sobre las aves rapaces diurnas. Hornero 22(02):141-147.

Zurita, G. A., G. Pe'er, M. I. Bellocq, and M. M. Hansbauer. 2012. Edge effects and their influence on habitat suitability calculations: a continuous approach applied to birds of the Atlantic forest. Journal of Applied Ecology 49:503-512. http://dx.doi.org/10.1111/ j.1365-2664.2011.02104.x
Editor-in-Chief: Ryan Norris Subject Editor: Fiona KASchmiegelow
Sponsored by the Society of Canadian Ornithologists and Bird Studies Canada Parrainée par la Société des ornithologistes du Canada et Études d'oiseaux Canada

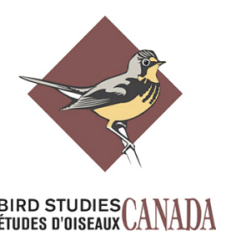




\section{Appendix 1}

Table A1.1 Bird species sampled in 45 forest patches during the austral fall-winter and spring-summer seasons of 2007 and 2008 in the province of Entre Ríos, Argentina. The code of species was determined by the first two letters of gender and the first two letters of the species.

\begin{tabular}{|c|c|c|}
\hline Scientific name & Common name & Code \\
\hline Columbina picui & Picui Ground Dove & COPI \\
\hline Agelaioides badius & Grayish Baywing & AGBA \\
\hline Drymornis bridgesii & Scimitar-billed Woodcreeper & DRBR \\
\hline Lepidocolaptes angustirostris & Narrow-billed Woodcreeper & LEAN \\
\hline Synallaxis frontalis & Sooty-fronted Spinetail & SYFR \\
\hline Pseudoseisura lophotes & Brown Cacholote & PSLO \\
\hline Taraba major & Great Antshrike & TAMA \\
\hline Polioptila dumicola & Masked Gnatcatcher & PODU \\
\hline Turdus rufiventris & Rufous-bellied Thrush & TURU \\
\hline Turdus amaurochalinus & Creamy-bellied Thrush & TUAM \\
\hline Saltator coerulescens ${ }^{\dagger}$ & Grayish Saltator & SACO \\
\hline Saltator aurantiirostris & Golden-billed Saltator & SAAU \\
\hline Paroaria coronata & Red-crested Cardinal & PACO \\
\hline Poospiza melanoleuca & Black-capped Warbling Finch & POME \\
\hline Suiriri & Suiriri Flycatcher & SUSU \\
\hline Serpophaga subcristata & White-crested Tyranulet & SESU \\
\hline Sicalis flaveola & Saffron Finch & SIFL \\
\hline Myiopsitta monachus & Monk Parakeet & MYMO \\
\hline Asthenes baeri ${ }^{\dagger}$ & Short-billed Canastero & ASBA \\
\hline
\end{tabular}




\section{Appendix 2}

Table A2.1 Producer's and user's accuracy for each cover type from Landsat TM image processing for 2007 and 2008.

\begin{tabular}{lcccc}
\hline \hline Class Name & \multicolumn{2}{c}{2007} & \multicolumn{2}{c}{2008} \\
& $\begin{array}{c}\text { Producer's } \\
\text { Accuracy } \\
(\%)\end{array}$ & $\begin{array}{c}\text { User's } \\
\text { Accuracy } \\
(\%)\end{array}$ & $\begin{array}{c}\text { Producer's } \\
\text { Accuracy } \\
(\%)\end{array}$ & $\begin{array}{c}\text { Uscer's } \\
\text { Accuracy } \\
(\%)\end{array}$ \\
\hline Water bodies & 97 & 99 & 99 & 99 \\
Corn & 70 & 71 & 69 & 68 \\
Sunflower & 100 & 63 & 99 & 82 \\
Soybean & 75 & 98 & 76 & 96 \\
Sorghum & 98 & 69 & 92 & 61 \\
Other crops & 82 & 80 & 71 & 80 \\
Introduced forest & 100 & 68 & 99 & 82 \\
Native forest & 72 & 85 & 91 & 91 \\
Flooded vegatation & 64 & 93 & 71 & 92 \\
Urban-bare soil & 92 & 95 & 87 & 89 \\
\hline
\end{tabular}




\section{Appendix 3}

A3. Description and ecological implication of native forest composition and configuration indexes used in the study as implemented in FRAGSTAT (McGarigal et al. 2012).

A3.1 Total area of native forests (FA)

$\sum_{j=1}^{a} a_{\mathrm{ij}}(1 / 10,000)$

$a_{\mathrm{ij}}=$ patch $\mathrm{ij}$ area $\left(\mathrm{m}^{2}\right)$

A3.2 Number of native forest patches (NP)

Number of patches

$\mathrm{NP}=\mathrm{n}_{\mathrm{i}}$

$\mathrm{n}_{\mathrm{i}}=$ number of patches in the landscape that belongs to the same class

A3.3 Mean patch area (PA)

$\sum_{j=1}^{n} x_{i j} / n_{i}$

$\mathrm{x}_{i \mathrm{j}}=$ all patches of the corresponding patch type

$\mathrm{n}_{\mathrm{i}}=$ number of patches

A3.4 Edge density (ED)

$\sum_{\mathrm{k}=1}^{\mathrm{m}} \mathrm{e}_{\mathrm{ik}} / \mathrm{A}(10,000)$

$e_{i k}=$ total length $(m)$ of edge in landscape involving patch type (class) $i$

$\mathrm{A}=$ total landscape area $\left(\mathrm{m}^{2}\right)$

A3.5 Shape index (SI)

$.25 \mathrm{p}_{\mathrm{ij}} / \sqrt{\mathrm{a}_{\mathrm{ij}}}$

$\mathrm{p}_{\mathrm{ij}}=$ perimeter $(\mathrm{m})$ of patch $\mathrm{ij}$

$\mathrm{a}_{\mathrm{ij}}=\operatorname{area}\left(\mathrm{m}^{2}\right)$ of patch $\mathrm{ij}$

A3.6 Fractal dimension index (FD)

$2 \ln \left(.25 \mathrm{p}_{\mathrm{ij}}\right) / \ln \mathrm{a}_{\mathrm{ij}}$

$\mathrm{p}_{\mathrm{ij}}=$ perimeter $(\mathrm{m})$ of patch $\mathrm{ij}$

$\mathrm{a}_{\mathrm{ij}}=\operatorname{area}\left(\mathrm{m}^{2}\right)$ of patch $\mathrm{ij}$

A3.7 Perimeter-area ratio (PARA)

$\mathrm{p}_{\mathrm{ij}} / \mathrm{a}_{\mathrm{ij}}$

$\mathrm{p}_{\mathrm{ij}}=$ perimeter $(\mathrm{m})$ of patch $\mathrm{ij}$ 
$\mathrm{a}_{\mathrm{ij}}=\operatorname{area}\left(\mathrm{m}^{2}\right)$ of patch $\mathrm{ij}$

A3.8 Mean Euclidean distance to forest patches (ENN)

$\mathrm{h}_{\mathrm{ij}}$

$\mathrm{h}_{\mathrm{ij}}=$ distance $(\mathrm{m})$ from patch $\mathrm{ij}$ to the nearest neighbor patch of the same class, based on patches edge to edge distance

A3.9 Cohesion index of forest patches $(\mathrm{COH})$

$\left[1-\sum_{j=1}^{n} p_{i j} / \sum_{j=1}^{n} p_{i j} \sqrt{a_{i j}}\right] \cdot[1-1 / \sqrt{Z}]^{-1} \cdot(100)$

$\mathrm{p}_{\mathrm{ij}}=$ patch ij perimeter (number of cells)

$\mathrm{a}_{\mathrm{ij}}=$ patch $\mathrm{ij}$ area (number of cells)

$\mathrm{Z}=$ total number of cells in the landscape

A3.10 Aggregation index of forest patches (AI)

$\left[\mathrm{g}_{\mathrm{ij}} / \max \rightarrow \mathrm{g}_{\mathrm{ij}}\right](100)$

$\mathrm{g}_{\mathrm{ii}}=$ number of like adjacencies (joins) between pixels of patch type (class) i based on the single-count method.

max $-g_{i i}=$ maximum number of like adjacencies 


\section{Appendix 4}

Table A4.1 Set of plausible models describing the relationship of within patch, patch and landscape variables with bird abundance for each season. Models are shown with their AICc values and Akaike weight ( $\omega$ i). Best set of models were those having $\triangle \mathrm{AICc}$ $\leq 2$ (Burnham and Anderson 2002). $\triangle \mathrm{AICc}=\mathrm{AICi}-\mathrm{AICmin}$ values. Parentheses indicate a negative relationship to bird abundance.

\begin{tabular}{|c|c|c|c|c|c|}
\hline Species $^{\dagger}$ & Season & Scale $\S$ & Model & $\mathrm{AICc}$ & Akaike weight ( $\omega$ i) \\
\hline \multirow[t]{17}{*}{ COPI } & \multirow[t]{8}{*}{ FW } & \multirow[t]{4}{*}{ Patch } & $\left(-\mathrm{D} \_\right.$Arb $)+\left(-\mathrm{D} \_\right.$arb $)$ & 117.46 & 0.36 \\
\hline & & & $\left(-\mathrm{D} \_\mathrm{Arb}\right)$ & 117.71 & 0.32 \\
\hline & & & $\left(-\mathrm{D} \_\right.$Arb $)+F D$ & 119.07 & 0.16 \\
\hline & & & $\left(-\mathrm{D} \_\mathrm{Arb}\right)+\left(-\mathrm{D} \_\right.$arb $)+\mathrm{FD}$ & 119.28 & 0.15 \\
\hline & & \multirow[t]{4}{*}{ Landscape } & $\mathrm{PC} 1$ & 30.52 & 0.37 \\
\hline & & & PC1 + Contagion & 31.94 & 0.18 \\
\hline & & & $\mathrm{PC} 1+(-\mathrm{IJI})$ & 32.29 & 0.15 \\
\hline & & & $\mathrm{PC} 1+\mathrm{PR}$ & 32.43 & 0.14 \\
\hline & \multirow[t]{9}{*}{ SS } & \multirow[t]{4}{*}{ Patch } & $\left(-\mathrm{D} \_\mathrm{Arb}\right)+\left(-\mathrm{D} \_\mathrm{arb}\right)$ & 114.42 & 0.28 \\
\hline & & & $\left(-\mathrm{D} \_\mathrm{Arb}\right)+\left(-\mathrm{D} \_\right.$arb $)+\mathrm{FD}$ & 114.54 & 0.26 \\
\hline & & & $\left(-\mathrm{D} \_\mathrm{Arb}\right)+\mathrm{FD}$ & 114.69 & 0.24 \\
\hline & & & $\left(-\mathrm{D} \_\right.$Arb $)$ & 115.54 & 0.16 \\
\hline & & \multirow[t]{5}{*}{ Landscape } & $\mathrm{PC} 1$ & 40.33 & 0.27 \\
\hline & & & $\mathrm{PC} 1+(-\mathrm{PR})$ & 41.67 & 0.14 \\
\hline & & & $\mathrm{PC} 1+\mathrm{PC} 2$ & 41.92 & 0.12 \\
\hline & & & $\mathrm{PC} 1+\mathrm{IJI}$ & 41.93 & 0.12 \\
\hline & & & $\mathrm{PC} 1+$ (-Contagion $)$ & 42.31 & 0.10 \\
\hline \multirow[t]{13}{*}{ AGBA } & \multirow[t]{7}{*}{ FW } & \multirow[t]{4}{*}{ Patch } & (-D_Arb) & 112.09 & 0.32 \\
\hline & & & $\left(-\mathrm{D} \_\mathrm{Arb}\right)+(-\mathrm{SI})$ & 112.68 & 0.24 \\
\hline & & & $\left(-\mathrm{D} \_\mathrm{Arb}\right)+(-\mathrm{CA})$ & 113.90 & 0.13 \\
\hline & & & $\left(-\mathrm{D} \_\mathrm{Arb}\right)+(-\mathrm{FD})$ & 114.10 & 0.12 \\
\hline & & \multirow[t]{3}{*}{ Landscape } & $(-\mathrm{PR})$ & 42.27 & 0.32 \\
\hline & & & $\mathrm{PC} 2+(-\mathrm{PR})$ & 43.64 & 0.16 \\
\hline & & & $\mathrm{PC} 1+(-\mathrm{PR})$ & 44.23 & 0.12 \\
\hline & \multirow[t]{6}{*}{ SS } & \multirow[t]{3}{*}{ Patch } & $\left(-D \_a r b\right)$ & 61.92 & 0.36 \\
\hline & & & (-D_Arb) & 63.39 & 0.17 \\
\hline & & & $\left(-D \_A r b\right)+\left(-D \_a r b\right)$ & 63.95 & 0.13 \\
\hline & & \multirow[t]{3}{*}{ Landscape } & $\mathrm{PC} 2+(-\mathrm{PR})$ & 13.54 & 0.20 \\
\hline & & & $\mathrm{PC} 2$ & 13.93 & 0.17 \\
\hline & & & $\mathrm{PC} 1+\mathrm{PC} 2$ & 14.67 & 0.12 \\
\hline \multirow[t]{7}{*}{ DRBR } & \multirow[t]{3}{*}{ FW } & \multirow[t]{2}{*}{ Patch } & $(-\mathrm{SI})$ & -47.41 & 0.57 \\
\hline & & & $(-\mathrm{SI})+(-\mathrm{FD})$ & -46.11 & 0.3 \\
\hline & & Landscape & $(-\mathrm{PC} 1)+(-\mathrm{IJI})$ & -40.63 & 0.49 \\
\hline & \multirow[t]{4}{*}{ SS } & \multirow[t]{3}{*}{ Patch } & $(-\mathrm{SI})+\mathrm{FD}+\mathrm{D} \_$Arb & -27.78 & 0.38 \\
\hline & & & D_Arb + DBH + (-A_Arb) & -27.03 & 0.26 \\
\hline & & & $(-\mathrm{SI})$ & -26.35 & 0.19 \\
\hline & & Landscape & $(-\mathrm{PC} 1)$ & -24.19 & 0.19 \\
\hline
\end{tabular}




\begin{tabular}{|c|c|c|c|c|c|}
\hline & & & $(-\mathrm{PC} 1)+$ Contagion & -24.07 & 0.18 \\
\hline & & & $(-\mathrm{PC} 1)+(-\mathrm{IJI})$ & -23.37 & 0.13 \\
\hline & & & $\mathrm{PC} 2+$ Contagion & -23.28 & 0.12 \\
\hline & & & Contagion & -23.17 & 0.11 \\
\hline & & & $(-P C 1)+P C 2$ & -22.74 & 0.09 \\
\hline LEAN & FW & Patch & D_Arb + (-SI) + (-FD) & 13.95 & 0.39 \\
\hline & & & D_Arb + A_Arb + DBH & 13.97 & 0.38 \\
\hline & & & D_Arb & 15.88 & 0.15 \\
\hline & & Landscape & $(-\mathrm{PC} 1)+(-$ Contagion $)$ & 1.41 & 0.44 \\
\hline & & & $(-\mathrm{PC} 1)$ & 3.29 & 0.17 \\
\hline & & & $(-\mathrm{PC} 1)+\mathrm{IJI}$ & 3.45 & 0.16 \\
\hline & SS & Patch & D_Arb + DBH & 6.80 & 0.69 \\
\hline & & & D_Arb + (-A_Arb $)+$ DBH & 8.53 & 0.29 \\
\hline & & Landscape & $(-\mathrm{PC} 1)+(-$ Contagion $)$ & -2.54 & 0.50 \\
\hline & & & $(-\mathrm{PC} 1)+\mathrm{IJI}$ & -0.73 & 0.20 \\
\hline SYFR & FW & Patch & FD + A_Arb & -51.00 & 0.77 \\
\hline & & Landscape & PR & -23.83 & 0.16 \\
\hline & & & IJI & -23.62 & 0.14 \\
\hline & & & (-Contagion) & -22.98 & 0.10 \\
\hline & & & $\mathrm{PC} 2$ & -22.81 & 0.10 \\
\hline & & & $(-\mathrm{PC} 1)+(-$ Contagion $)$ & -22.42 & 0.08 \\
\hline & & & $\mathrm{PC} 2+\mathrm{PR}$ & -22.23 & 0.07 \\
\hline & & & $(-\mathrm{PC} 1)$ & -21.92 & 0.06 \\
\hline & SS & Patch & $\mathrm{FD}+\mathrm{A} \_\mathrm{Arb}$ & 46.46 & 0.57 \\
\hline & & & A_Arb & 47.82 & 0.29 \\
\hline & & Landscape & (-Contagion) & 12.94 & 0.20 \\
\hline & & & $\mathrm{PC} 2$ & 13.40 & 0.16 \\
\hline & & & $\mathrm{PC} 2+(-$ Contagion $)$ & 14.46 & 0.09 \\
\hline & & & $\mathrm{PC} 2+\mathrm{PR}$ & 14.57 & 0.09 \\
\hline & & & $(-\mathrm{PC} 1)+(-$ Contagion $)$ & 14.80 & 0.08 \\
\hline PSLO & FW & Patch & $(-\mathrm{SI})$ & 12.52 & 0.49 \\
\hline & & & $(-\mathrm{SI})+(-\mathrm{FD})$ & 13.30 & 0.33 \\
\hline & & Landscape & $(-\mathrm{PC} 1)+(-\mathrm{PR})$ & -4.89 & 0.31 \\
\hline & & & $(-\mathrm{PC} 1)$ & -4.69 & 0.28 \\
\hline & SS & Patch & D_Arb + (-SI) + (-FD) & -15.81 & 0.26 \\
\hline & & & D_Arb & -15.45 & 0.22 \\
\hline & & & D_Arb + (-A_Arb) + DBH & -15.23 & 0.20 \\
\hline & & & $(-\mathrm{SI})+(-\mathrm{FD})$ & -14.66 & 0.15 \\
\hline & & Landscape & $(-\mathrm{PC} 1)$ & -13.45 & 0.37 \\
\hline & & & $(-\mathrm{PC} 1)+(-\mathrm{PR})$ & -11.54 & 0.14 \\
\hline & & & $(-\mathrm{PC} 1)+(-\mathrm{IJI})$ & -11.52 & 0.14 \\
\hline TAMA & FW & Patch & D_Arb + A_Arb + SI & 20.25 & 0.52 \\
\hline & & & D_Arb + D_arb + A_Arb & 22.22 & 0.19 \\
\hline & & Landscape & $\mathrm{PC} 2$ & 8.95 & 0.21 \\
\hline & & & (-Contagion) & 9.91 & 0.13 \\
\hline & & & $\mathrm{PC} 2+\mathrm{IJI}$ & 10.24 & 0.11 \\
\hline
\end{tabular}




\begin{tabular}{|c|c|c|c|c|c|}
\hline & & & IJI & 10.31 & 0.11 \\
\hline & & & $\mathrm{PC} 2+(-$ Contagion $)$ & 10.69 & 0.09 \\
\hline & SS & Patch & D_Arb + A_Arb + SI & -75.22 & 0.78 \\
\hline & & Landscape & $\mathrm{PC} 2$ & -34.65 & 0.15 \\
\hline & & & $\mathrm{PC} 2+\mathrm{PR}$ & -34.50 & 0.14 \\
\hline & & & PR & -34.15 & 0.12 \\
\hline & & & $\mathrm{PC} 1+(-$ Contagion $)$ & -33.87 & 0.10 \\
\hline & & & IJI & -33.62 & 0.09 \\
\hline & & & (-Contagion) & -33.20 & 0.07 \\
\hline & & & $\mathrm{PC} 1+\mathrm{PC} 2$ & -33.07 & 0.07 \\
\hline & & & $\mathrm{PC} 2+\mathrm{IJI}$ & -33.00 & 0.07 \\
\hline PODU & $\mathrm{FW}$ & Patch & (-D_Arb) & 83.37 & 0.37 \\
\hline & & & $\left(-\mathrm{D} \_\mathrm{Arb}\right)+\left(-\mathrm{D} \_\right.$arb $)$ & 84.01 & 0.27 \\
\hline & & & $\left(-\mathrm{D} \_\mathrm{Arb}\right)+\mathrm{FD}$ & 84.43 & 0.22 \\
\hline & & Landscape & $\mathrm{PC} 1$ & 12.33 & 0.34 \\
\hline & & & $\mathrm{PC} 1+(-\mathrm{PR})$ & 12.80 & 0.27 \\
\hline & & & $\mathrm{PC} 1+\mathrm{IJI}$ & 14.19 & 0.13 \\
\hline & & & $\mathrm{PC} 1+\mathrm{PC} 2$ & 14.33 & 0.12 \\
\hline & SS & Patch & $\left(-\mathrm{D} \_A r b\right)$ & -6.24 & 0.61 \\
\hline & & & $\left(-\mathrm{D} \_\right.$Arb $)+$D_arb & -4.21 & 0.22 \\
\hline & & Landscape & $\mathrm{PC} 1$ & -20.03 & 0.33 \\
\hline & & & $\mathrm{PC} 1+(-\mathrm{PR})$ & -19.17 & 0.21 \\
\hline & & & $\mathrm{PC} 1+\mathrm{PC} 2$ & -18.71 & 0.17 \\
\hline & & & $\mathrm{PC} 1+\mathrm{IJI}$ & -18.36 & 0.14 \\
\hline & & & $\mathrm{PC} 1+(-$ Contagion $)$ & -18.12 & 0.13 \\
\hline TURU & FW & Patch & D_arb + D_Arb & -127.47 & 0.56 \\
\hline & & Landscape & $\mathrm{PC} 2+$ Contagion & -9.97 & 0.27 \\
\hline & & & Contagion & -8.87 & 0.16 \\
\hline & SS & Patch & D_Arb & -153.84 & 0.39 \\
\hline & & & D_Arb + A_Arb + DistLoc & -152.73 & 0.22 \\
\hline & & & A_Arb & -151.85 & 0.14 \\
\hline & & Landscape & $\mathrm{PC} 2+$ Contagion & -71.88 & 0.23 \\
\hline & & & PC2 & -71.69 & 0.21 \\
\hline & & & $(-\mathrm{PC} 1)+\mathrm{PC} 2$ & -71.51 & 0.19 \\
\hline & & & $\mathrm{PC} 2+\mathrm{PR}$ & -71.12 & 0.16 \\
\hline TUAM & FW & Patch & DistLoc & -13.30 & 0.34 \\
\hline & & & $(-\mathrm{SI})+$ DistLoc & -12.66 & 0.25 \\
\hline & & & $(-\mathrm{SI})$ & -12.48 & 0.23 \\
\hline & & Landscape & $(-\mathrm{PC} 1)+(-\mathrm{PC} 2)$ & -24.22 & 0.47 \\
\hline & & & $(-\mathrm{PC} 1)+$ Contagion & -22.75 & 0.23 \\
\hline & SS & Patch & A_Arb + (-DBH) & -18.31 & 0.32 \\
\hline & & & A_Arb & -18.15 & 0.29 \\
\hline & & & A_Arb + D_Arb & -17.97 & 0.27 \\
\hline & & Landscape & $(-\mathrm{PC} 1)+(-$ Contagion $)$ & -14.38 & 0.30 \\
\hline & & & $(-\mathrm{PC} 1)+\mathrm{IJI}$ & -13.11 & 0.16 \\
\hline & & & IJI & -12.48 & 0.12 \\
\hline
\end{tabular}




\begin{tabular}{|c|c|c|c|c|c|}
\hline \multirow[t]{14}{*}{ SAAU } & \multirow[t]{7}{*}{ FW } & \multirow[t]{4}{*}{ Patch } & D_Arb + A_Arb & 63.45 & 0.26 \\
\hline & & & D_Arb & 63.58 & 0.24 \\
\hline & & & DistLoc & 63.58 & 0.24 \\
\hline & & & FD + DistLoc & 64.30 & 0.17 \\
\hline & & \multirow[t]{3}{*}{ Landscape } & $(-\mathrm{PC} 1)+\mathrm{IJI}$ & 15.80 & 0.31 \\
\hline & & & $(-\mathrm{PC} 1)$ & 17.02 & 0.17 \\
\hline & & & IJI + Contagion & 17.29 & 0.15 \\
\hline & \multirow[t]{7}{*}{ SS } & \multirow[t]{4}{*}{ Patch } & D_Arb + A_Arb + (-DBH) & 60.85 & 0.32 \\
\hline & & & D_Arb + A_Arb & 60.96 & 0.31 \\
\hline & & & D_Arb & 61.64 & 0.22 \\
\hline & & & D_Arb + D_arb + A_Arb & 62.38 & 0.15 \\
\hline & & \multirow[t]{3}{*}{ Landscape } & $(-\mathrm{PC} 1)+\mathrm{IJI}$ & 21.72 & 0.33 \\
\hline & & & IJI & 22.25 & 0.25 \\
\hline & & & IJI + Contagion & 23.33 & 0.15 \\
\hline \multirow[t]{9}{*}{ PACO } & \multirow[t]{7}{*}{ FW } & \multirow[t]{4}{*}{ Patch } & $(-\mathrm{SI})$ & 118.48 & 0.34 \\
\hline & & & $(-\mathrm{SI})+(-\mathrm{FD})+$ DistLoc & 119.26 & 0.23 \\
\hline & & & $(-\mathrm{SI})+(-\mathrm{FD})$ & 119.84 & 0.17 \\
\hline & & & D_Arb & 120.29 & 0.14 \\
\hline & & \multirow[t]{3}{*}{ Landscape } & $(-\mathrm{PC} 1)$ & 34.75 & 0.33 \\
\hline & & & $(-\mathrm{PC} 1)+(-\mathrm{PR})$ & 36.18 & 0.16 \\
\hline & & & $(-\mathrm{PC} 1)+(-\mathrm{PC} 2)$ & 36.29 & 0.15 \\
\hline & \multirow[t]{2}{*}{ SS } & Patch & $(-\mathrm{SI})$ & 43.38 & 0.51 \\
\hline & & Landscape & $(-\mathrm{PC} 1)+(-\mathrm{PR})$ & 3.97 & 0.90 \\
\hline \multirow[t]{11}{*}{ POME } & \multirow[t]{6}{*}{ FW } & Patch & $\left(-\mathrm{D} \_\mathrm{Arb}\right)+(-\mathrm{DBH})$ & -19.70 & 0.91 \\
\hline & & Landscape & $(-\mathrm{PC} 2)$ & -16.02 & 0.20 \\
\hline & & & Contagion & -15.33 & 0.14 \\
\hline & & & $(-\mathrm{PC} 2)+\mathrm{IJI}$ & -14.41 & 0.09 \\
\hline & & & $(-\mathrm{PR})$ & -14.09 & 0.08 \\
\hline & & & $(-\mathrm{PC} 2)+(-\mathrm{PR})$ & -14.00 & 0.07 \\
\hline & \multirow[t]{5}{*}{ SS } & Patch & $\mathrm{CA}+(-\mathrm{SI})+\mathrm{FD}$ & -33.21 & 0.98 \\
\hline & & Landscape & $(-\mathrm{PC} 1)$ & -20.01 & 0.25 \\
\hline & & & $(-\mathrm{PC} 1)+(-\mathrm{PC} 2)$ & -18.77 & 0.14 \\
\hline & & & $(-\mathrm{PC} 1)+(-\mathrm{PR})$ & -18.29 & 0.11 \\
\hline & & & $(-\mathrm{PC} 1)+\mathrm{IJI}$ & -18.23 & 0.10 \\
\hline \multirow[t]{12}{*}{ SUSU } & \multirow[t]{6}{*}{ FW } & \multirow[t]{2}{*}{ Patch } & $(-\mathrm{FD})$ & -88.69 & 0.57 \\
\hline & & & $\mathrm{SI}+(-\mathrm{FD})$ & -87.53 & 0.32 \\
\hline & & \multirow[t]{4}{*}{ Landscape } & $(-\mathrm{PC} 1)$ & -45.33 & 0.32 \\
\hline & & & $(-\mathrm{PC} 1)+(-\mathrm{PC} 2)$ & -43.52 & 0.13 \\
\hline & & & $(-\mathrm{PC} 1)+$ Contagion & -43.30 & 0.11 \\
\hline & & & $(-P C 1)+P R$ & -43.28 & 0.11 \\
\hline & \multirow[t]{6}{*}{ SS } & \multirow[t]{3}{*}{ Patch } & $\mathrm{CA}+(-\mathrm{FD})$ & 44.09 & 0.45 \\
\hline & & & $\mathrm{CA}+\mathrm{SI}+(-\mathrm{FD})$ & 45.00 & 0.28 \\
\hline & & & $\mathrm{CA}$ & 45.12 & 0.27 \\
\hline & & \multirow[t]{3}{*}{ Landscape } & $(-\mathrm{PC} 1)$ & 6.47 & 0.15 \\
\hline & & & PR & 6.73 & 0.13 \\
\hline & & & $\mathrm{PC} 2$ & 7.02 & 0.11 \\
\hline
\end{tabular}




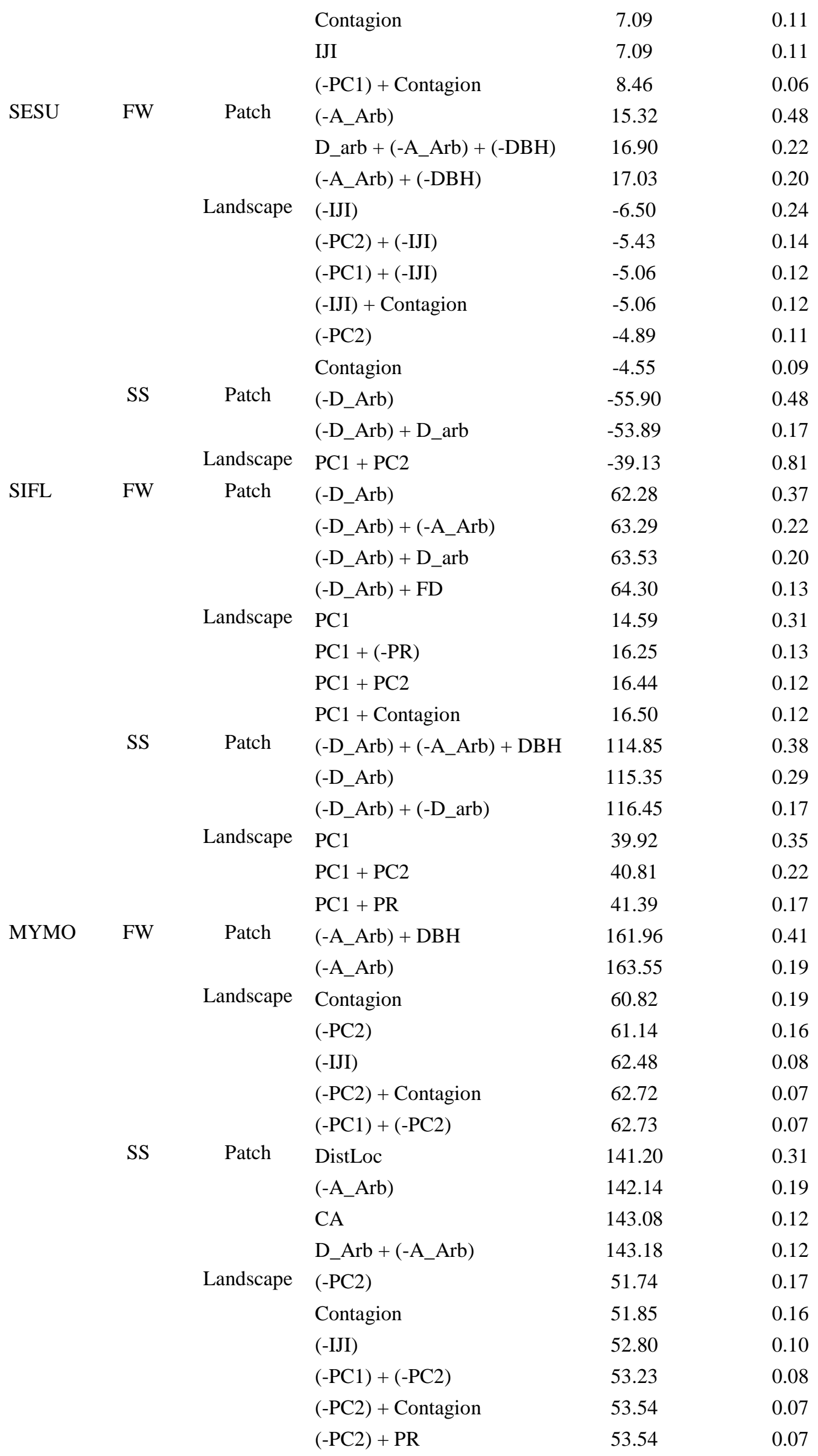




\begin{tabular}{|c|c|c|}
\hline$(-\mathrm{PC} 1)$ & 53.71 & 0.06 \\
\hline$(-\mathrm{PC} 2)+(-\mathrm{IJI})$ & 53.72 & 0.06 \\
\hline Codes of bird species listed in Table A1.1. & & \\
\hline ‡Seasons: $\mathrm{FW}=$ fall-winter, $\mathrm{SS}=$ spring-su & & \\
\hline $\begin{array}{l}\text { §Spatial scale: Patch-scale variables: D_Art } \\
\text { shrubs, A Arb = tree height, DBH = diame }\end{array}$ & $\begin{array}{l}\text { ees, } D_{-} \\
\text {ght, PA }\end{array}$ & $\begin{array}{l}\text { sity of } \\
\text { rea (ha), SI= }\end{array}$ \\
\hline Shape index, FD $=$ fractal dimension, DistL & hce $(\mathrm{m})$ & st settlement. \\
\hline Landscape spatial configuration: $\mathrm{PC} 1=$ frag & lient pri & mponent, \\
\hline PC2 = fragmentation covariate principal co & nterspe & \\
\hline
\end{tabular}




\section{Appendix 5}

Table A5.1 Mosaic description based on patch and landscape variables during 2007 and 2008 in the province of Entre Ríos, Argentina. Values are mean \pm SE in ().

\begin{tabular}{|c|c|c|c|c|c|}
\hline Scale & Variable & Description & Mosaic I & Mosaic II & Mosaic III \\
\hline \multirow[t]{9}{*}{ Patch } & \multicolumn{5}{|c|}{ Measured on the 45 patches of forest } \\
\hline & D_Arb & Mean tree density (indiv/ha) & $355.49( \pm 36.35)^{\mathrm{a}}$ & $451.18( \pm 24.73)^{\mathrm{a}}$ & $166.05( \pm 28.90)^{\mathrm{b}}$ \\
\hline & D_arb & Mean shrub density (indiv/ha) & $528.47( \pm 84.21)$ & $462.30( \pm 79.18)$ & $288.77( \pm 46.48)$ \\
\hline & A_Arb & Mean tree height $(\mathrm{m})$ & $4.44( \pm 0.18)^{\mathrm{a}}$ & $5.39( \pm 0.18)^{\mathrm{b}}$ & $4.83( \pm 0.22)^{\mathrm{ab}}$ \\
\hline & DBH & Mean diameter at breast height & $15.76( \pm 0.92)$ & $17.04( \pm 0.87)$ & $15.94( \pm 0.97)$ \\
\hline & $\mathrm{PA}$ & Patch area (ha) & $33.73( \pm 7.20)$ & $48.55( \pm 11.75)$ & $29.21( \pm 7.41)$ \\
\hline & SI & Shape index & $1.35( \pm 0.05)^{\mathrm{a}}$ & $1.45( \pm 0.08)^{\mathrm{a}}$ & $1.63( \pm 0.09)^{\mathrm{b}}$ \\
\hline & FD & Mean patch fractal dimension & $1.26( \pm 0.01)^{\mathrm{a}}$ & $1.26( \pm 0.01)^{\mathrm{a}}$ & $1.29( \pm 0.01)^{\mathrm{b}}$ \\
\hline & DistLoc & $\begin{array}{l}\text { Mean linear distance to nearest } \\
\text { settlement }(\mathrm{m})\end{array}$ & $8923.8( \pm 1138.33)$ & $4869.73( \pm 657.08)$ & $7104.33( \pm 1213.52)$ \\
\hline \multirow{11}{*}{$\begin{array}{l}\text { Landscape } \\
\text { (Forest } \\
\text { class) }\end{array}$} & \multicolumn{5}{|c|}{ Measured on the 18 sub-landscapes } \\
\hline & FA & Total cover of forest areas (ha) & $5617.21( \pm 410.33)^{\mathrm{a}}$ & $2308.67( \pm 295.69)^{\mathrm{ab}}$ & $303.58( \pm 134.50)^{\mathrm{b}}$ \\
\hline & NP & Total number of forest patches & $24.58( \pm 2.82)^{\mathrm{ab}}$ & $39.50( \pm 5.36)^{\mathrm{a}}$ & $17.33( \pm 5.26)^{\mathrm{b}}$ \\
\hline & PA & Mean area of forest patches (ha) & $253.95( \pm 40.03)^{\mathrm{a}}$ & $64.36( \pm 12.85)^{\mathrm{ab}}$ & $15.12( \pm 4.19)^{\mathrm{b}}$ \\
\hline & $\mathrm{ED}$ & Edge density (m/ha) & $53.27( \pm 4.02)^{\mathrm{a}}$ & $110.06( \pm 16.26)^{\mathrm{ab}}$ & $368.76( \pm 81.84)^{b}$ \\
\hline & SI & Shape index & $2.09( \pm 0.08)^{\mathrm{a}}$ & $2.18( \pm 0.11)^{\mathrm{a}}$ & $4.18( \pm 0.69)^{\mathrm{b}}$ \\
\hline & FD & Fractal dimension & $1.10( \pm 0.01)^{\mathrm{a}}$ & $1.10( \pm 0.01)^{\mathrm{a}}$ & $1.16( \pm 0.01)^{\mathrm{b}}$ \\
\hline & PARA & Area-perimeter ratio & $1167.49( \pm 343.40)$ & $450.17( \pm 79.80)$ & $664.97( \pm 135.34)$ \\
\hline & ENN & $\begin{array}{l}\text { Mean euclidean distance among } \\
\text { forest patches }(\mathrm{m})\end{array}$ & $57.83( \pm 7.83)^{\mathrm{a}}$ & $157.14( \pm 112.19)^{\mathrm{b}}$ & $833.22( \pm 395.73)^{\mathrm{b}}$ \\
\hline & $\mathrm{COH}$ & Forest patch cohesion & $99.94( \pm 0.03)^{\mathrm{a}}$ & $99.71( \pm 0.05)^{\mathrm{a}}$ & $99.11( \pm 0.15)^{b}$ \\
\hline & AI & Aggregation index & $99.33( \pm 0.05)^{\mathrm{a}}$ & $98.60( \pm 0.23)^{\mathrm{ab}}$ & $93.82( \pm 1.92)^{\mathrm{b}}$ \\
\hline
\end{tabular}


Landscape Measured on the 18 sub-landscapes (all class)

$\begin{array}{ll}\text { CO } & \text { Contagion } \\ \text { IJI } & \text { Interspersion and Juxtaposition } \\ \text { PR } & \end{array}$

\begin{tabular}{cccccc}
2007 & 2008 & 2007 & 2008 & 2007 & 2008 \\
54.31 & 56.91 & 52.12 & 46.02 & 54.09 & 44.52 \\
$( \pm 2.71)$ & $( \pm 2.07)^{\mathrm{a}}$ & $( \pm 1.22)$ & $( \pm 1.42)^{\mathrm{b}}$ & $( \pm 1.35)$ & $( \pm 0.54)^{\mathrm{b}}$ \\
59.22 & 67.44 & 62.46 & 70.59 & 60.49 & 67.46 \\
$( \pm 1.04)$ & $( \pm 1.82)$ & $( \pm 0.91)$ & $( \pm 20.05)$ & $( \pm 1.95)$ & $( \pm 1.04)$ \\
10.50 & 9.50 & 10.50 & 9.50 & 9.50 & 9.33 \\
$( \pm 0.22)$ & $( \pm 0.22)$ & $( \pm 0.34)$ & $( \pm 0.22)$ & $( \pm 0.43)$ & $( \pm 0.33)$ \\
\hline
\end{tabular}

${ }^{\mathrm{a}}$ and ${ }^{\mathrm{b}}$ indicate statistical differences of variables between mosaics. Means with a common letter are not significantly different $(\mathrm{P}>$ 0.05 ) by Kruskal Wallis test. 


\section{Appendix 6}

Table A6.1 Correlation matrix of forest patch scale and landscape variables. D_Arb = density of trees, D_arb = density of shrubs, A_Arb = tree height, $\mathrm{DBH}=$ diameter at breast height, $\mathrm{PA}=$ patch area $(\mathrm{ha}), \mathrm{SI}=$ Shape index, $\mathrm{FD}=$ fractal dimension, DistLoc $=$ linear distance $(\mathrm{m})$ to nearest settlement, $\mathrm{PC} 1=$ fragmentation gradient principal component, $\mathrm{PC} 2=$ fragmentation covariate principal component, $\mathrm{IJI}=$ interspersion and juxtaposition, $\mathrm{CO}=$ Contagion and $\mathrm{PR}=$ cover type richness.

\begin{tabular}{|c|c|c|c|c|c|c|c|c|c|c|c|c|}
\hline & D_Arb & D_arb & A_Arb & $\mathrm{DBH}$ & PA & SI & FD & DistLoc & $\mathrm{PC} 1$ & PC2 & IJI & Contagion \\
\hline D_arb & 0.49 & & & & & & & & & & & \\
\hline A_Arb & 0.33 & -0.02 & & & & & & & & & & \\
\hline DBH & 0.08 & -0.28 & 0.67 & & & & & & & & & \\
\hline PA & 0.03 & -0.03 & 0.17 & 0.08 & & & & & & & & \\
\hline SI & -0.33 & -0.06 & -0.03 & -0.19 & 0.24 & & & & & & & \\
\hline FD & -0.32 & -0.12 & -0.20 & -0.23 & -0.34 & $0.74 *$ & & & & & & \\
\hline DistLoc & 0.04 & 0.02 & -0.53 & -0.27 & -0.23 & 0.08 & 0.33 & & & & & \\
\hline PC1 & -0.69 & -0.45 & -0.02 & 0.01 & 0.06 & 0.69 & 0.58 & -0.16 & & & & \\
\hline $\mathrm{PC} 2$ & 0.28 & -0.03 & $0.79 *$ & 0.50 & 0.15 & 0.03 & -0.09 & -0.20 & 0.01 & & & \\
\hline IJI & 0.32 & -0.19 & 0.53 & 0.39 & -0.06 & -0.06 & 0.05 & 0.12 & -0.11 & 0.57 & & \\
\hline Contagion & 0.05 & 0.31 & -0.62 & -0.46 & -0.14 & -0.36 & -0.26 & 0.18 & -0.47 & $-0.74 *$ & -0.61 & \\
\hline PR & 0.51 & 0.47 & 0.26 & 0.02 & 0.23 & -0.09 & -0.16 & -0.10 & -0.52 & 0.28 & -0.25 & 0.15 \\
\hline
\end{tabular}

$* \mathrm{P}=0.05$ 